\title{
Dentate Gyrus Development Requires ERK Activity to Maintain Progenitor Population and MAPK Pathway Feedback Regulation
}

\author{
이oseph Vithayathil, ${ }^{1}{ }^{-}$Joanna Pucilowska, ${ }^{1}$ L. Henry Goodnough, ${ }^{2}$ Radhika P. Atit, ${ }^{3}$ and Gary E. Landreth ${ }^{1}$ \\ Departments of ${ }^{1}$ Neurosciences, ${ }^{2}$ Pathology, and ${ }^{3}$ Biology, Case Western Reserve University, Cleveland, 0 hio 44106
}

\begin{abstract}
The ERK/MAPK pathway is an important developmental signaling pathway. Mutations in upstream elements of this pathway result in neuro-cardio-facial cutaneous (NCFC) syndromes, which are typified by impaired neurocognitive abilities that are reliant upon hippocampal function. The role of ERK signaling during hippocampal development has not been examined and may provide critical insight into the cause of hippocampal dysfunction in NCFC syndromes. In this study, we have generated ERK1 and conditional ERK2 compound knock-out mice to determine the role of ERK signaling during development of the hippocampal dentate gyrus. We found that loss of both ERK1 and ERK2 resulted in 60\% fewer granule cells and near complete absence of neural progenitor pools in the postnatal dentate gyrus. Loss of ERK1/2 impaired maintenance of neural progenitors as they migrate from the dentate ventricular zone to the dentate gyrus proper, resulting in premature depletion of neural progenitor cells beginning at E16.5, which prevented generation of granule cells later in development. Finally, loss of ERK2 alone does not impair development of the dentate gyrus as animals expressing only ERK1 developed a normal hippocampus. These findings establish that ERK signaling regulates maintenance of progenitor cells required for development of the dentate gyrus.
\end{abstract}

Key words: dentate gyrus; ERK; MAPK pathway; NCFC; neurogenesis

\section{Introduction}

The extracellular signal-regulated kinases (ERKs) are the central components of the mitogen-activated protein kinase (MAPK) signaling pathway. Mutations in various elements of the MAPK pathway are genetically linked to a collection of related disorders termed neuro-cardio-facial cutaneous (NCFC) syndromes, which include the broadly termed "RASopathies" (Samuels et al., 2009; Rauen, 2013). These disorders arise from both loss- and gain-offunction mutations within this pathway and exhibit overlapping phenotypes. Importantly, these syndromes are characterized by intellectual disability, developmental delay, and psychiatric disorders, which include various degrees of cognitive impairment (Bentires-Alj et al., 2006; Tidyman and Rauen, 2009; Tartaglia and Gelb, 2010; Zenker, 2011; Adviento et al., 2014).

Initial studies of ERK1/2 signaling in the adult brain found that these enzymes were essential for regulating synaptic plastic-

Received 0ct. 9, 2014; revised March 20, 2015; accepted March 23, 2015.

Author contributions: J.V., J.P., and G.E.L. designed research; J.V. and L.H.G. performed research; J.P., L.H.G., R.P.A., and G.E.L. contributed unpublished reagents/analytic tools; J.V. and J.P. analyzed data; J.V. wrote the paper.

This work was supported by the Simons Foundation (Grant SFARI ID 275316 to G.E.L.) and the National Institutes of Health, National Institute of Dental and Craniofacial Research Grant R01 DE01870 to R.P.A., National Institute of Dental and Craniofacial Research GrantF31 DE020220 to L.H.G., and National Institutes of Health Grant T32 GM007250 to J.V. We thank the Animal Resource Center staff and J. Colleen Karlo for maintaining animal colonies; and the Case Western Reserve University Neuroscience Imaging core for use of the Zeiss LSM510 META confocal microscope.

The authors declare no competing financial interests.

Correspondence should be addressed to Dr. Gary E. Landreth, Department of Neurosciences, Case Western Reserve University School of Medicine, 10900 Euclid Avenue, Cleveland, OH 44106. E-mail: gel2@case.edu.

DOI:10.1523/JNEUROSCI.4196-14.2015

Copyright $\odot 2015$ the authors $\quad 0270-6474 / 15 / 356836-13 \$ 15.00 / 0$ ity in the hippocampus and spatial memory retention (English and Sweatt, 1997; Selcher et al., 1999). Although these studies ascertained the importance of ERK signaling in the adult hippocampus, the role of ERK1/2 during hippocampal development has not been extensively studied. This is an important question as the hippocampus is necessary for cognition and learning, which are impaired in patients with NCFC syndromes (Yoon et al., 2007; Pierpont et al., 2013). In the current study, we use a forebrain-specific knock-out of the Mapk1 (ERK2) and germline knock-out of Mapk3 (ERK1) to examine the formation of the dentate gyrus (DG).

Morphogenesis of the DG has been studied primarily in the context of the Wnt and Reelin signaling cascades, whereas the effect of ERK MAPK signaling on DG and hippocampal morphogenesis is less understood (Roelink, 2000; Zhou et al., 2004). FGFs are the prototypic activators of the ERK MAPK pathway during telencephalic development (Eswarakumar et al., 2005; Thomson et al., 2007). Mice lacking FGFR1 exhibit a significantly smaller hippocampus, although there are no cytoarchitectural impairments (Ohkubo et al., 2004). Whether these defects are due to diminished ERK activity is unknown, and the role of ERK1/2 activity during DG development has not been explored.

Development of the DG requires precise control of transcription factor cascades that orchestrate the differentiation of progenitor cells into mature neurons (Pleasure et al., 2000; Hevner et al., 2006; Sugiyama et al., 2013). Neural progenitors populate three proliferative zones: the ventricular zone (VZ) of the hippocampus (primary dentate matrix), a secondary germinal zone 
(secondary dentate matrix), and the tertiary zone (tertiary dentate matrix). The tertiary dentate matrix is located in the presumptive DG, whereas the secondary dentate matrix is the dentate migratory stream (DMS), which is formed as neural progenitors migrate from the VZ to the developing DG (Altman and Bayer, 1990). Most granule cells in the DG are born during the first postnatal week in mice, which is much later compared with the cortex, where neurogenesis occurs embryonically ( $\mathrm{Li}$ and Pleasure, 2007; Yu et al., 2014).

In our study, we find that loss of both ERK1 and ERK2 results in a smaller DG due to depletion of progenitors, which subsequently impairs generation of granule cells in the developing DG.

\section{Materials and Methods}

Mice. All mice used were on a C57/B6 background and of mixed gender. Floxed Mapk1 (ERK2) alleles were created by flanking exon 2 of the Mapk1 gene with loxP sites and knocked-in to the endogenous locus (Samuels et al., 2008). Emx-Cre mice were obtained from The Jackson Laboratory. Mapk3 (ERK1) null mice were generated previously (Nekrasova et al., 2005). Mice were housed in the Animal Resource Center on a $12 \mathrm{~h}$ light-dark cycle, provided food ad libitum, and maintained using standard animal housing protocols. For timed matings, plug date was designated as E0.5 and birth was designated as P0. For BrdU labeling, pregnant dams were injected with $50 \mathrm{mg} / \mathrm{kg}$ BrdU (Roche) at indicated ages.

Protein extraction and Western blots. Pregnant dams were killed at gestation day E14.5, and pups were removed. Tails were collected for genotyping. The mice were decapitated, and brains were removed. The dorsal telencephalon was dissected into cold HBSS and disrupted to create single-cell suspension. Cells were centrifuged and the HBSS aspirated. Protein was extracted by resuspending cells in lysis buffer $(20 \mathrm{~mm}$ Tris$\mathrm{HCl}, 150 \mathrm{~mm} \mathrm{NaCl}, 1 \mathrm{~mm}$ EGTA, $1.5 \mathrm{~mm} \mathrm{MgCl}, 20 \mathrm{~mm} \mathrm{NaF}, 20 \mathrm{~mm}$ $\beta$-glycerol phosphate, $1 \% \mathrm{NP} 40,10 \%$ glycerol, $\mathrm{pH} 7.5$ ) containing protease and phosphatase inhibitors (Sigma). Samples were centrifuged at $15,000 \mathrm{rpm}$ to pellet debris. The supernatant was collected, and the protein was quantified using a BCA assay (Thermo Scientific reagents). Protein samples (15-20 $\mu \mathrm{g})$ were run on 9\% SDS-PAGE gel and transferred onto PVDF membrane. Blots were blocked using 5\% milk (Carnation) or $5 \%$ BSA (Sigma) in 0.1\%TBS-Tween-20 (TBST) for $1 \mathrm{~h}$ at room temperature. Primary antibodies used were as follows: phospho-ERK1/2 (Cell Signaling Technology, 1:5000), ERK1/2 (Cell Signaling Technology, 1:5000), phospho-MEK (Cell Signaling Technology, 1:1000), MEK1/2 (Cell Signaling Technology, 1:1000), phospho-C-Raf(S259) (Cell Signaling Technology, 1:2000), C-Raf (Cell Signaling Technology, 1:1000), Sprouty1 (Cell Signaling Technology, 1:1000), phospho-GSK3 $\beta$ (Ser9) (BD Biosciences, 1:100), GSK3 $\beta$ (BD Biosciences PharMingen, 1:1000), $\beta$-catenin (BD Biosciences, 1:10,000), Axin2 (Abcam, 1:1000), Reelin (Millipore, 1:1000), and tubulin (LI-COR, 1:1000). Blots were incubated overnight at $4^{\circ} \mathrm{C}$ with primary antibody diluted in $5 \%$ milk unless specified by the manufacturer. Blots were washed in TBST and incubated in HRP-conjugated secondary antibodies (Sigma) or 680/800 fluorophoreconjugated secondary antibodies (LI-COR) for $1 \mathrm{~h}$ at room temperature. Pierce ECL chemiluminescence substrate was used for signal detection, and blots were imaged using a Protein Simple M-Fluorchem or X-ray film (Kodak). Fluorescent blots were imaged using the Odyssey Fc (LI-COR). Densitometry analysis was conducted using ImageJ. Phosphorylated ERK, MEK, C-Raf, and GSK3 $\beta$ were normalized to total ERK, MEK, C-Raf, and GSK3 $\beta$, respectively. All other proteins were normalized to actin or tubulin. GraphPad software was used for statistical analysis.

Immunohistochemistry/immunofluorescence. Pups were harvested at E16.5, E18.5, P2, and P10. Brains were dissected and drop-fixed in $4 \%$ PFA overnight. Brains were incubated in sucrose solutions of $10 \%, 20 \%$, and $30 \%$ with $24 \mathrm{~h}$ incubation at each sucrose concentration. Tissue was embedded in OCT followed by preparation of $10 \mu \mathrm{m}$ coronal sections using Leica cryostat. Sections were matched and rehydrated in PBS. Sections underwent antigen retrieval (Reveal Decloaker, Biocare) for $10 \mathrm{~min}$ and blocked using $5 \%$ NGS in $0.1 \%$ PBS-Triton X-100 or Sniper Solution (Biocare). Sections were incubated with primary antibody overnight at $4^{\circ} \mathrm{C}$. Primary antibodies used were as follows: Proxl (Millipore, 1:1000), Tbr2 (Millipore, 1:1000), Ctip2 (Abcam, 1:250), BrdU (Abcam, 1:100), BrdU (Caltag, 1:500), activated-caspase3 (Cell Signaling Technology, 1:100), phospho-H3 (Millipore, 1:200), Nestin (Millipore, 1:500), p73 (Santa Cruz Biotechnology, 1:250), CXCR4 (Thermo Scientific, 1:250), calretinin (Swant, 1:1000), L1-CAM (Millipore, 1:250), Pax6 (Covance, 1:200), phospho-ERK1/2 (Cell Signaling Technology, 1:250), phosphoMEK1/2 (Cell Signaling Technology, 1:250), and GFAP (Dako, 1:500). AlexaFluor secondary antibodies (Invitrogen) were used for fluorescent detection followed by DAPI counterstaining and mounting using Prolong Gold Anti-Fade (Invitrogen). For DAB staining, endogenous peroxides were quenched using $3 \%$ hydrogen peroxide before blocking. Sections were treated with the appropriate biotinylated secondary antibodies, followed by DAB substrate (Vectastain). Sections were then counterstained with cresyl violet and coverslipped with Permount (Sigma). Phospho-ERK immunofluorescence was performed using a Tyramide Amplification kit (PerkinElmer). For cell counts, 3 or 4 images of the septal hippocampus were taken per animal and 3-6 animals were used for each analysis. Blinded cell counts were obtained using Adobe Photoshop and averaged for each animal. GraphPad software was used for statistical analysis.

In situ hybridization. Slides with E14.5 sections were postfixed in 4\% PFA for $10 \mathrm{~min}$, incubated with Proteinase $\mathrm{K}$ for $1 \mathrm{~min}$, followed by another 4\% PFA 10 min incubation. Sections were then acetylated with acetic anhydride in TEA buffer for $10 \mathrm{~min}$. The sections were washed, dehydrated in ethanol, and air-dried. Sections were then incubated for 30 min in Tris/glycine buffer. Slides were incubated overnight at $65^{\circ} \mathrm{C}$ in probe diluted in hybridization buffer. Wnt3a probes: Wnt $3 a$ forward, CACCACCGTCAGCAACAGCC; Wnt3a reverse, AGGAGCGTGTCACTGCGAAAG. Hybridization buffer: $40 \%$ formamide, $5 \times$ SSC, $1 \times$ Denhardt's (Sigma), $100 \mu \mathrm{g} / \mathrm{ml}$ fish testis DNA (Sigma), $100 \mu \mathrm{g} / \mathrm{ml}$ yeast tRNA (Sigma) in water. Probe and hybridization mix was heated at $95^{\circ} \mathrm{C}$ for $2 \mathrm{~min}$ before adding to sections. Sections were washed in SSC buffer, treated with RNase for $30 \mathrm{~min}$, and then incubated in 1\% blocking reagent (Roche) for $10 \mathrm{~min}$. Sections were then incubated in anti-Dig antibody (Roche) overnight at $4^{\circ} \mathrm{C}$. Slides were then washed in TBS followed by incubation in $0.5 \mathrm{mg} / \mathrm{ml} \mathrm{levamisol} \mathrm{(Sigma)} \mathrm{in} 0.1 \%$ Tween 20 in water. Sections were then incubated in BM purple (Roche) overnight in the dark at $4^{\circ} \mathrm{C}$ until staining was apparent. Sections were washed in $1 \mathrm{~mm}$ EDTA to stop reaction and coverslipped with mounting media (Dako).

\section{Results}

\section{Loss of both ERK1 and ERK2 causes dysregulation of the MAPK signaling cascade}

ERK1/2 expression is highest in proliferating neural progenitors positioned in the VZ and subventricular zone (SVZ) of the developing telencephalon, which includes the hippocampus (Imamura et al., 2010; Satoh et al., 2011; Pucilowska et al., 2012). To study the role of ERK1/2 in the hippocampal development, the Mapk1 gene (ERK2) was conditionally deleted using an Emx1Cre (hereafter termed ERK2 CKO), which is expressed in radial glia beginning at E9.5 in the dorsal telencephalon (Gorski et al., 2002). To generate both ERK1 and ERK2 double knock-outs (DKO), ERK2 was conditionally knocked out using Emx1-Cre in Mapk3 (ERK1) null mice. Whereas CKO mice exhibited normal survival, DKO mice died 3-4 weeks after birth as reported previously (Pucilowska et al., 2012). However, the fact that DKO mice survive the first two postnatal weeks allowed analysis of the development of the hippocampal DG.

We first confirmed that ERK1/2 protein was absent in the mutant mice. At E14.5, a Western blot analysis showed significant reduction of ERK2 in both ERK2 CKO and ERK1/2 DKO animals, whereas ERK1 is absent in only the DKO animals (Figure 1A). CKO mice showed an elevation in ERK1 phosphorylation, which is likely a compensatory response to loss of ERK2 (Figure $1 A, B)$. Mutant animals are compared with control ERK2 ${ }^{\text {flox/flox }}$ mice, which hereafter are referred to as WT mice. 
A

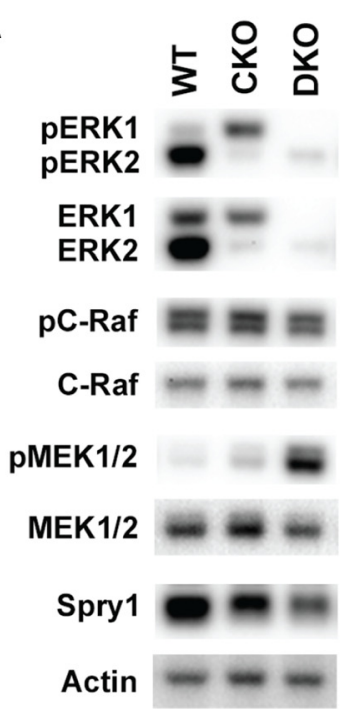

B

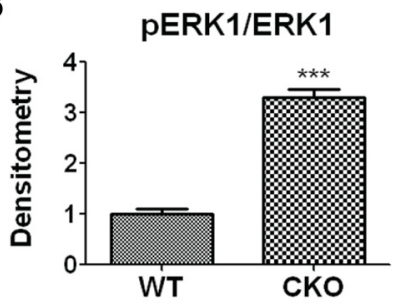

D

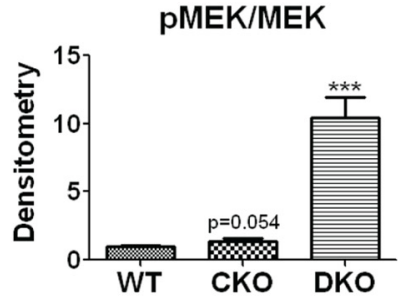

C

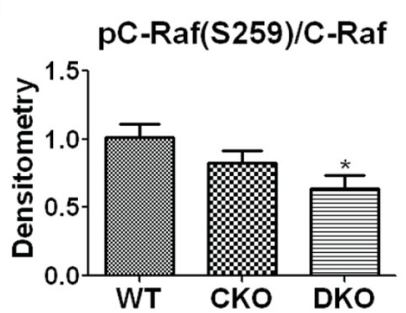

$\mathbf{E}$

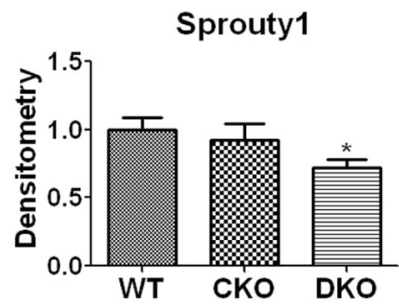

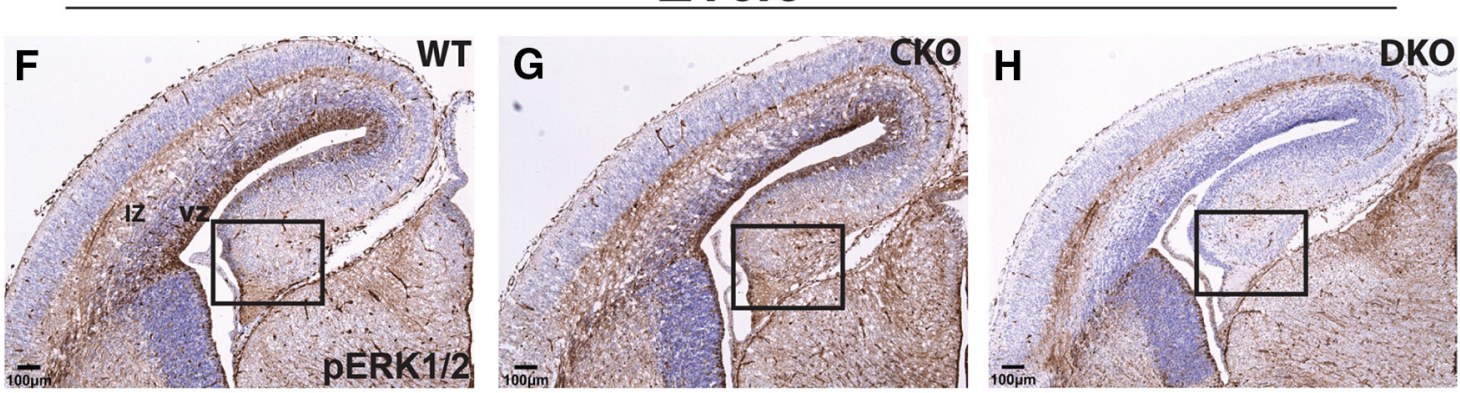
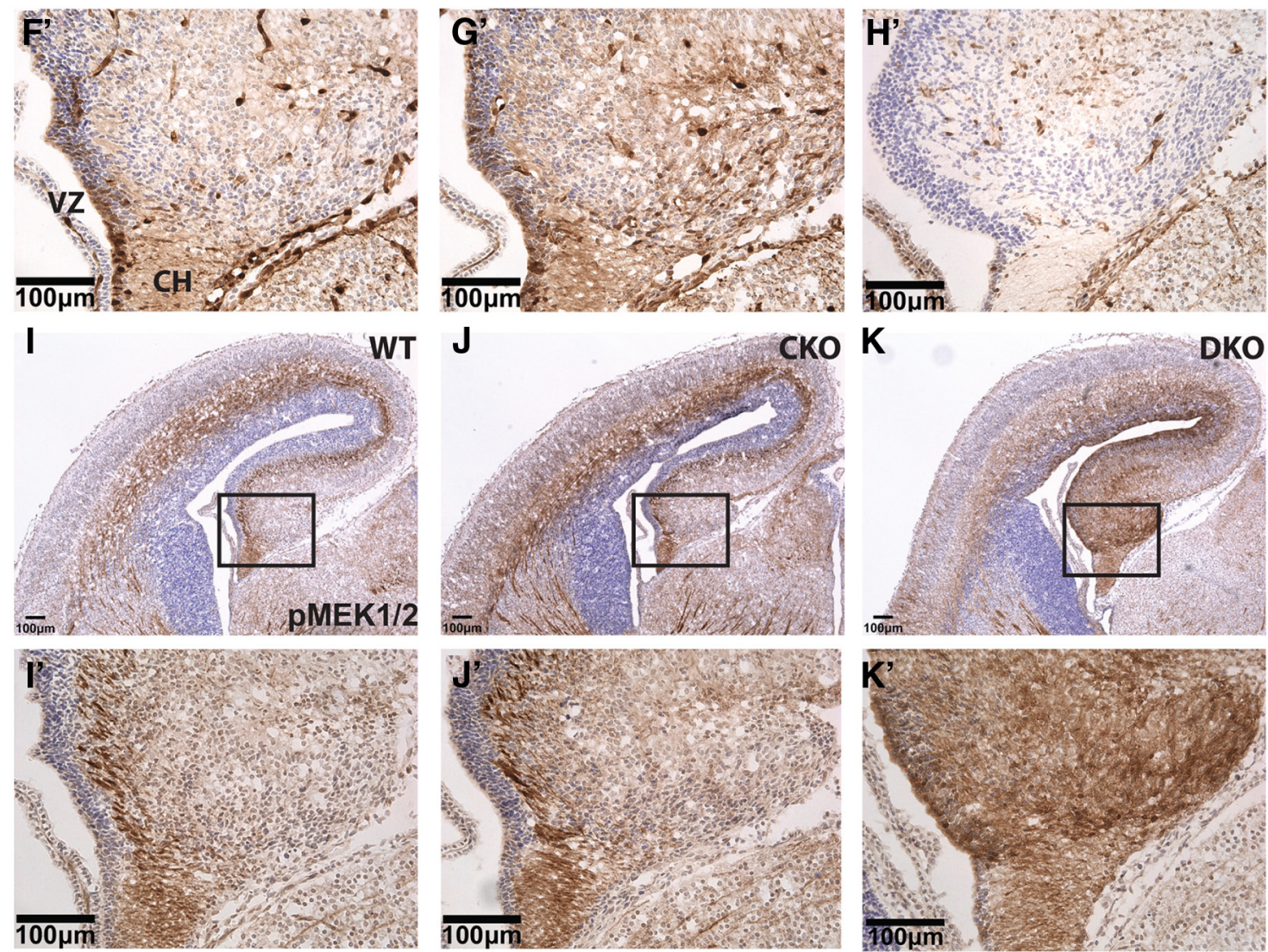

Figure 1. Loss of ERK activity in the dorsal telencephalon impairs negative feedback regulation of the MAPK pathway. $A$, WB showing loss of ERK2 in the CKO mice and loss of both ERK1 and ERK2 in DK0 mice at E14.5. Blots also show phosphorylation of MEK1/2, phosphorylation of C-Raf (S259) and Spry1 in the dorsal telencephalon at E14.5. B, Densitometric analysis of phospho-ERK1 in dorsal telencephalon of E14.5 WT and CKO mice (normalized to total ERK1). ${ }^{* *} p<0.0001$ ( $t$ test). Mean \pm SEM: WT: $1.000 \pm 0.1029, N=6 ;$ CK0:3.306 $\pm 0.1571, N=10$. (Figure legand continues) 
ERK1 and ERK2 have many cytoplasmic and nuclear targets, including those that provide crucial negative feedback regulation of their upstream activators, most prominently the Raf kinases and MEK1/2 (Hanafusa et al., 2002; Dougherty et al., 2005; Catalanotti et al., 2009). The effect of ERK1 and/or ERK2 loss of function on the MAPK/ERK pathway was assessed by examining the activation of upstream kinases C-Raf and MEK1/2. Phosphorylation of C-Raf on S259 inhibits C-Raf activity and is one site of negative feedback regulation. Western blot analysis of C-Raf phosphorylation at S259 revealed a gene dose-dependent decrease in C-Raf phosphorylation. ERK2 CKO showed nonsignificant declines in phospho-C-Raf (S259), whereas ERK1/2 DKO displayed a 46\% decrease in C-Raf (S259) phosphorylation ( $t$ test, $p=0.0244)$, indicating increased activity of C-Raf (Fig. $1 \mathrm{~A}, \mathrm{C})$. Compared with WT mice, ERK2 CKO animals displayed no change in MEK1/2 activation, as reflected by the levels of the phosphorylated enzymes. Remarkably, ERK1/2 DKO animals displayed a 10-fold increase in MEK phosphorylation ( $t$ test, $p<$ 0.0001 ) in the developing dorsal telencephalon at E14.5 (Fig. $1 A, D)$. ERK activity also drives expression of MAPK pathway regulators, such as Sproutyl (Spry1), which is significantly decreased in the DKO mice at E14.5, indicating that the MAPK pathway is disinhibited ( $t$ test, $p=0.027$ ) (Fig. $1 A, E$ ).

We show that ERK1/2 activity is restricted primarily to the VZ and intermediate zone (IZ) of the developing telencephalon in E16.5 tissue from WT and CKO mice (Fig. $1 F, G$ ). PhosphoERK1/2 (pERK) levels are much higher in the cortical VZ compared with the dentate VZ. Within the hippocampus, phospho-ERK1/2 immunoreactivity appears in the VZ as well as the cortical hem (Fig. $1 F^{\prime}, G^{\prime}$ ). In DKO mice, we observed a complete loss of ERK1/2 signaling in the VZ of the dorsal telencephalon, but phospho-ERK1/2 immunoreactivity is maintained in the IZ, which contains neurons and projections originating in areas where Cre is not expressed (Fig. $1 \mathrm{H}, \mathrm{H}^{\prime}$ ).

In addition, analysis of the distribution of activated phosphoMEK1/2 showed higher expression in the VZ of ERK1/2 DKO mice at E16.5 compared with WT and CKO mice (Fig. $1 I-K, I^{\prime}-$ $\left.K^{\prime}\right)$. These findings highlight the hyperactivation of upstream components of the MAPK pathway due to loss of ERK1/2dependent negative feedback. However, interestingly, loss of ERK2 alone in CKO mice resulted in minimal disruption of feedback to upstream elements of this pathway both by IHC and Western blot. Therefore, the presence of ERK1 is sufficient to regulate feedback loops in the MAPK pathway.

To determine which cells in the IZ and VZ exhibit ERK activity, we examined multiple cell populations for phospho-ERK immunoreactivity (Fig. 2). At E16.5, phospho-ERK in the VZ colocalized with Nestin ${ }^{+}$radial glial cells of WT mice, which was not observed in DKO mice (Fig. $2 A, A^{\prime}, A 1-A 4, B, B^{\prime}, B 1-B 4$ ). In

$\leftarrow$

(Figure legand continues.) C, Densitometric analysis of C-Raf S259 phosphorylation, which is an inhibitory phosphorylation site (normalized to total C-Raf). ${ }^{*} p=0.024$ ( $t$ test). Mean \pm SEM:WT: $1.01 \pm 0.104, N=13 ;$ CKO: $0.8285 \pm 0.088, N=14 ;$ DK0: $0.6398 \pm 0.098, N=13$. D. Densitometry analysis of activated phosphorylated MEK1/2 (normalized to total MEK1/2). ${ }^{* * *} p<0.0001$ (ttest). Mean \pm SEM:WT: $1.000 \pm 0.07801, N=9$; CKO: $1.395 \pm 0.1549, N=$ 12; DK0: $10.47 \pm 1.465, N=14$. E, Densitometric analysis of Sprouty1 (normalized to actin). ${ }^{*} p=0.027$ (t test). Mean \pm SEM: WT: $1.000 \pm 0.09, N=9$; CKO:0.9240 $\pm 0.12, N=8$; DKO: $0.7177 \pm 0.067, \mathbf{N}=8 . \boldsymbol{F}-\boldsymbol{H}, \boldsymbol{F}^{\prime}-\boldsymbol{H}^{\prime}$, IHC of phospho-ERK1/2 in the dorsal telencephalon of E16.5 WT $\left(\boldsymbol{F}, \boldsymbol{F}^{\prime}\right)$, CKO $\left(\boldsymbol{G}, \boldsymbol{G}^{\prime}\right)$, and DKO mice $\left(\boldsymbol{H}, \boldsymbol{H}^{\prime}\right) . \boldsymbol{F}^{\prime}-\boldsymbol{H}^{\prime}$, Increased magnification of the VZ of the DG. CH, Cortical hem. Scale bar, $100 \mu \mathrm{m}$. $\boldsymbol{I}-\boldsymbol{K}, \boldsymbol{I}^{\prime}-\boldsymbol{K}^{\prime}$, IHC of phospho-MEK1/2 in the dorsal telencephalon of E16.5 WT $\left(\boldsymbol{I}, \boldsymbol{I}^{\prime}\right)$, CKO $\left(\boldsymbol{J}, \boldsymbol{J}^{\prime}\right)$, and DKO mice $\left(\boldsymbol{K}, \boldsymbol{K}^{\prime}\right)$. $\boldsymbol{I}^{\prime}-\boldsymbol{K}^{\prime}$, Increased magnification of the VZ of the DG. Scale bar, $100 \mu \mathrm{m}$. the IZ, ERK activity persisted in the DKO animals. There are multiple cell populations in this zone; however, the only ones that do not express the Cre recombinase are migrating interneurons from the ventral telencephalon and thalamocortical axon projections from thalamus. We observed phospho-ERK colocalization with the neural cell adhesion molecule L1, which labels thalamocortical projections (Fig. $2 C, C^{\prime}, C 1-C 4$ ) as well as CXCR4, a marker for migrating interneurons (Fig. 2D, $D^{\prime}, D 1-D 4$ ). These studies show that the ERK activity is present in migrating interneurons and thalamocortical axons, which retain ERK2 expression in the DKO mice as expected. Finally, we assessed whether ERK activity changes later in development by examining phospho-ERK immunoreactivity in the hippocampus of $\mathrm{P} 2$ mice (Fig. 2E, F). Interestingly, phospho-ERK signaling appears strongest in the developing CA1 stratum radiatum (SR) and stratum lacunosum moleculare (SLM). There is also modest colocalization with $\mathrm{TuJ1}$, a marker for processes of postmitotic neurons (Fig. $2 E^{\prime}, F^{\prime}, E 1-E 4, F 1-F 4$ ). DKO mice show very little phosphoERK immunoreactivity, but TuJ1 expression is present. These data show that, as development proceeds, ERK activity appears in postmitotic neurons.

\section{Loss of both ERK1 and ERK2 impairs morphogenesis of the DG}

We examined the hippocampus of postnatal day 10 (P10) mice and observed severe hypoplasia of the hippocampus in the ERK1/2 DKO mice (Fig. 3). When granule cells are first generated, they begin expressing Prox 1 , a marker of immature and mature granule cells that populate the DG (Oliver et al., 1993; Liu et al., 2000; Lavado and Oliver, 2007). Mature granule cells subsequently express Ctip2 as well as Prox1 (Simon et al., 2012). To examine the granule cells of the DG, WT and DKO tissue were immunostained for Ctip2 and Prox1 (Fig. $3 A, A^{\prime}$ ). DKO mice exhibited a $62.4 \%$ reduction in total Prox ${ }^{+}$granule cells in the hippocampus compared with WT mice $(t$ test, $p=0.0012)$ (Fig. $3 B)$. When we stratified granule cells as mature Ctip $2^{+}$cells or immature Ctip2 ${ }^{-}$granule cells, we observed only a $47.5 \%$ reduction ( $t$ test, $p=0.0068)$ in Ctip ${ }^{+}$granule cells, but a $90.3 \%$ reduction ( $t$ test, $p=0.0001$ ) in Ctip2 ${ }^{-}$immature granule cells in DKO mice compared with WT (Fig. 3B). ERK2 CKO mice show no difference in the number of DG granule cells compared with WT littermates (Fig. 3B). These data suggest that DKO mice possess granule cells that were generated early in development but lack granule cells that are generated at later developmental times.

Granule cells are generated from neural progenitor cells that sequentially express different transcription factors as they mature and differentiate. Primary neural stem cells express classical radial glia cell markers (Pax6, Nestin). As these cells divide and mature, they produce intermediate progenitor cells (IPCs) that are defined by their expression of Tbr2 (Hevner et al., 2006; Sugiyama et al., 2013; Yu et al., 2014). Recently, deletion of Tbr2 was shown to result in hypoplasia of the hippocampus (Arnold et al., 2008; Hodge et al., 2012). Because the majority of granule cells are produced during the first postnatal week, progenitor populations were examined in the P10 hippocampus (Fig. $3 A, A^{\prime}$ ). Interestingly, the hippocampus of DKO mice contained almost no $\mathrm{Tbr}^{+}$neural IPCs with $94.1 \%$ fewer $\mathrm{Tbr} 2^{+}$progenitors compared with WT ( $t$ test, $p=0.0008$ ) (Fig. 3C). ERK2 CKO mice showed no changes in $\mathrm{Tbr} 2^{+}$populations either in their spatial distribution or total numbers. Finally, the structure of the DG in the DKO mice was extremely dysmorphic, but both the suprapyramidal and infrapyramidal blades of the DG were present. Development of the two blades of the DG has been shown to be 

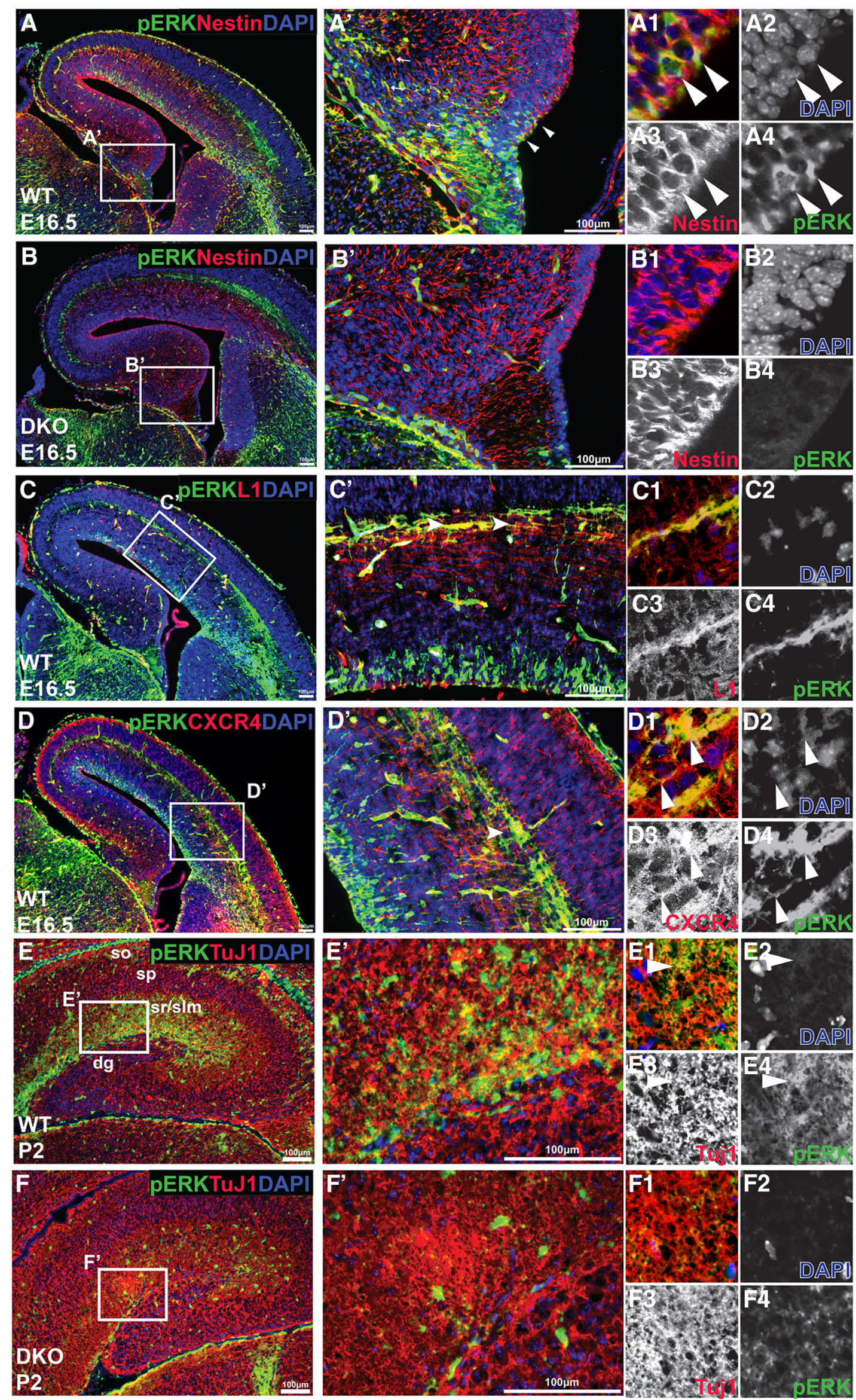
dependent on Cajal-Retzius (C-R) cells and scaffolding provided by radial glial cells that migrate into the DG and reside in the subgranular zone of the DG (Rickmann et al., 1987). Analysis of the Nestin ${ }^{+}$radial glial cells revealed that DKO mice contain very few Nestin ${ }^{+}$radial glia that extend processes through the granule cell layer of the DG compared with WT (Fig. 3D, $D^{\prime}$ ).

Additionally, we analyzed ERK activity within the P10 hippocampus of WT and DKO mice (Figure $3 E, E^{\prime}$ ). In WT mice, ERK activity was primarily found in the stratum oriens (SO), SR, and SLM in CA1 region. In the DG, ERK activity is located in the inner molecular layer (IML) where commissural/associational fibers from hilar mossy cells form synapses with the dendrites of granule cells. In the DKO mice, we observe very little phosphoERK expression, except for some immunoreactivity in the developing SLM and hilar neurons.

These results indicate that inactivation of both ERK isoforms results in severe dysmorphia of the hippocampus accompanied by a complete loss of progenitor cells. Interestingly, presence of ERK1 alone was sufficient for normal hippocampal development.

\section{Loss of ERK signaling impairs granule cell generation}

To analyze development of the DG in DKO mice, we analyzed the cellular composition of the DG between E16.5 and P2 (Fig. 4A$\left.C, A^{\prime}-C^{\prime}\right)$. At E16.5 and E18.5, DKO mice exhibit normal numbers of Prox ${ }^{+}$granule cells in the DG compared with WT and ERK2 CKO mice (Fig. 4D). By P2, however, DKO mice show a $25.3 \%$ reduction of Prox ${ }^{+}$granule cells $(t$ test, $p=0.0495)$ in the DG that becomes more apparent at P10 (Fig. 4D). Interestingly, $\mathrm{Tbr}{ }^{+}$IPCs show an even greater reduction over the same interval. Specifically, the DKO mice have slightly increased numbers of Tbr ${ }^{+}$progenitors in the DG at E16.5 (Fig. 4E). By E18.5, there is a $29.4 \%$ decrease in Tbr2 ${ }^{+}$IPCs $(t$ test, $p=0.0014)$, and by $\mathrm{P} 2$ this effect is amplified with a $65.7 \%$ decrease in this population of cells ( $t$ test, $p<0.0001$ ) (Fig. $4 E$ ). These data demonstrate a rapid decline in the number of $\mathrm{Tbr} 2{ }^{+}$progenitors that leads to impaired granule cell production postnatally. Quantitation of $\mathrm{Tbr} 2{ }^{+}$progenitors revealed that, starting at E16.5, there is a steady decline in their number, indicative of their progressive depletion. In contrast, WT and ERK2 CKO mice show early expansion of $\mathrm{Tbr}_{2}{ }^{+}$progenitors in the DG that only starts to decline postnatally. Importantly, the decline in Tbr $2^{+}$IPCs in DKO mice precedes the decline in Prox $1^{+}$granule cells, which is consistent with the fact that the $\mathrm{Tbr} 2^{+}$IPCs are generating granule cells. We observed high levels of phospho-ERK signaling around the fissure where $\mathrm{Tbr} 2^{+}$cells are located during DG develop-

\section{$\leftarrow$}

Figure 2. ERK signaling is present in radial glial cells, migrating interneurons, and thalamocortical axons. $\boldsymbol{A}, \boldsymbol{B}, \boldsymbol{A}^{\prime}, \boldsymbol{B}^{\prime}$, IHC of pERK (green), Nestin (red), and DAPI (blue) in an E16.5 forebrain of WT $\left(\boldsymbol{A}, \boldsymbol{A}^{\prime}\right)$ and DKO $\left(\boldsymbol{B}, \boldsymbol{B}^{\prime}\right)$ mice at both low magnification $(\boldsymbol{A}, \boldsymbol{B})$ and higher magnification of the dentate VZ $\left(\boldsymbol{A}^{\prime}, \boldsymbol{B}^{\prime}, \boldsymbol{A 1}-\boldsymbol{A 4}, \boldsymbol{B} 1-B 4\right)$. Arrowheads indicate colocalization in the VZ. Arrows point to colocalization in processes extending into the DG. Scale bar, $100 \mu \mathrm{m}$. C, $\boldsymbol{C}^{\prime}$, IHC of pERK (green), L1 (red), and DAPI (blue) in an E16.5 forebrain of a WT mouse (C). Magnification of boxed area in $\mathbf{C}$, with arrowheads indicating colocalization $\left(\boldsymbol{C}^{\prime}\right) \cdot \mathbf{C 1}$-C4, Higher magnification of individual $\mathrm{L1}^{+}$fibers that colocalize with phospho-ERK immunoreactivity. Scale bar, $100 \mu \mathrm{m} . \boldsymbol{D}, \boldsymbol{D}^{\prime}$, IHC of pERK (green), CXCR4 (red), and DAPI (blue) in an E16.5 forebrain of a WT mouse $(\boldsymbol{D})$. Magnification of boxed area in $\boldsymbol{D}$, with arrowheads indicating colocalization ( $\boldsymbol{D}^{\prime}, \mathbf{D 1}$-D4). Scale bar, $100 \mu \mathrm{m} . \boldsymbol{E}, \boldsymbol{F}, \boldsymbol{E}^{\prime}, \boldsymbol{F}^{\prime}$, IHC of phospho-ERK (green), TuJ1 (red), and DAPI (blue) in a P2 hippocampus of WT and DKO mouse. so, Stratum oriens; sp, stratum pyramidale; sr/slm, stratum radiatum/straum lacunosum moleculare; dg, dentate gyrus. $\boldsymbol{E}, \boldsymbol{F}$, Boxes are magnified to show the SR/SLM $\left(\boldsymbol{E}^{\prime}, \boldsymbol{F}^{\prime}\right)$. $\boldsymbol{E 1 - E 4 , F 1 - F 4 , ~ H i g h - m a g n i f i c a t i o n ~ i m a g e s ~}$ showing individual immunoreactivity of TuJ1 and phospho-ERK as well as the overlay. Arrowheads indicate colocalization. Scale bar, $100 \mu \mathrm{m}$. ment. Interestingly, we observed that $\mathrm{Tbr} 2^{+}$cells express only low levels of phospho-ERK immunoreactivity, which is highlighted in the magnified images (Figure $4 F, F^{\prime}$ ).

To determine whether the decline in granule cells is due to their diminished generation, BrdU birthdating studies were conducted. Pregnant dams were injected with a single $50 \mathrm{mg} / \mathrm{kg}$ dose of BrdU at E18.5 and pups were killed at P2. The hippocampus was immunostained for BrdU and Prox1 to identify granule cells born at the time of BrdU injection (Fig. 5A, $A^{\prime}$ ). The P2 DKO DG exhibits a $38 \%$ decrease in $\mathrm{BrdU}^{+} / \mathrm{Prox}^{+}$colabeled cells in DKO mice compared with WT ( $t$ test, $p=0.04$ ) (Fig. $5 B$ ). These findings demonstrate a significant decline in Prox ${ }^{+}$granule cell production at E18.5.

To rule out apoptotic cell death as a possible cause of declining granule cell numbers, we examined apoptosis in P2 brains. Activated-caspase 3 (AC3) staining in P2 brain sections showed no changes in apoptosis in DKO mice compared with WT mice in the DG, although we did observe a trend toward increased AC3 immunoreactivity in CA1 (Fig. $5 C, C^{\prime}, D$ ). These results indicate that production of granule cells declines starting at E18.5, due to progenitor cell depletion and not cell death. This decline in granule cell production is especially problematic for the DG where the majority of granule cell production occurs postnatally. ERK2 CKO mice showed no difference in granule cell generation indicating that minimal ERK activity is sufficient for normal hippocampal development.

\section{Radial glial population is depleted in DG proper of DKO mice} We wanted to determine whether the depletion of granule cells was due to perturbations in the radial glial cells in addition to IPCs. To answer this question, we analyzed the number of mitotic cells (cells in M-phase) present in the VZ of the DG by quantifying cells positive for $\mathrm{PH} 3$, which labels cells in M phase. Interestingly, we found that the mitotic activity was decreased by $21.4 \%$ in the DKO mice compared with WT mice ( $t$ test, $p=0.024)$. CKO mice showed no changes in mitotic activity compared with WT (Fig. $6 A, A^{\prime}, B$ ). Thus, the loss of both ERK isoforms decreases mitotic activity, as previously observed in the developing cortex (Pucilowska et al., 2012).

When we examined the population of radial glial cells in the developing DG, we found that the number of Pax6 radial glial cells was also not significantly different at E16.5 in DKO mice compared with CKO and WT in any of the germinal zones (Fig. $\left.6 A, A^{\prime}, D\right)$. However, by E18.5, the dentate VZ of the DKO mice exhibit a $27.5 \%$ reduction in $\mathrm{Pax}^{+}{ }^{+}$radial glia $(t$ test, $p=0.03)$, whereas the DMS or secondary germinal matrix of DKO mice showed a $38.2 \%$ reduction in Pax6 ${ }^{+}$cells compared with WT $(t$ test, $p=0.0009$ ). Interestingly, in the DG germinal zone (tertiary germinal matrix), there was a much larger $58 \%$ reduction in Pax $6^{+}$cells in the DKO mice compared with WT ( $t$ test, $p=$ 0.0017 ) (Fig. $6 C, C^{\prime}, E$ ). To determine whether ERK activity is present in the Pax6 ${ }^{+}$radial glial cells, we examined Pax6 ${ }^{+}$cells for phospho-ERK expression (Fig. $6 F, G$ ). We observed that in WT tissue, Pax6 ${ }^{+}$cells in the primordial DG expressed low levels of phospho-ERK, which was absent in the DKO mice. We also observed similar findings in the VZ and DMS as well (data not shown). These data show that the loss of ERK1/2 causes a decrease in VZ mitotic activity at E16.5, whereas depletion of radial glial cells appears after E16.5, where the developing DG is more significantly affected compared with the dentate VZ.

Although DKO mice show significant depletion of Pax6 ${ }^{+}$radial glial cells, it is unclear what happens to these cells. To address this question, we evaluated radial glial cell maturation. As the 
radial glial cells in the dentate $\mathrm{VZ}$ mature, they express GFAP at the dentate VZ-fimbria junction (Fox et al., 2004; Barry et al., 2008). We found that in DKO mice there is no phospho-ERK immunoreactivity in the VZ-fimbria junction, and the resident radial glial cells express much higher levels of GFAP compared with WT mice at E16.5 (Fig. 6H,I). However, the radial glial cells in the DKO still extend processes into the DG that allow for migration of progenitors into the DG from the VZ. By P2 the radial glial cell population is located in the tertiary germinal zone, and we observed that WT mice display $\mathrm{GFAP}^{+}$ radial glial cells that extend processes through the DG as part of the scaffold necessary for DG morphogenesis (Fig. 6J, J1). Interestingly, DKO mice do not exhibit any $\mathrm{GFAP}^{+}$cells with a radial glial morphology (Fig. $6 K, K 1$ ), which has been observed previously (Imamura et al., 2010). Higher-magnification images show that $\mathrm{GFAP}^{+}$cells in WT mice exhibit radial processes that extend vertically to the fissure, whereas DKO mice exhibit GFAP ${ }^{+}$ cells with multiple horizontal processes and appear astrocytic in nature (Fig. $6 L, M)$, These data show that the depletion of $\mathrm{Pax}^{+}$cells in the DG of DKO mice is due to precocious maturation of the radial glial cells and subsequent differentiation.

\section{$\mathrm{C}-\mathrm{R}$ cells are reduced in postnatal DKO mice}

Whereas radial glial cells form one component of the scaffolding necessary for migration of progenitors from the $\mathrm{VZ}$ to the DG, the other cell type necessary for DG formation are the C-R cells. C-R cells are typically present at E10.5 and form the marginal zone of the dorsal telencephalon (Bayer and Altman, 1990; Bielle et al., 2005). One of their critical functions is to secrete Reelin, which is an important signaling molecule that regulates the layering of the cortex and hippocampus by guiding the migration of neurons into their correct position (Frotscher et al., 2003; GilSanz et al., 2013). They are also vital for the formation of the hippocampal fissure, and loss of Reelin or C-R cells results in dysgenesis of the DG (Yang et al., 2000; Meyer et al., 2004). C-R cells are among the earliest neurons in the telencephalon and originate from a few different regions, one of which is the cortical hem (Abraham et al., 2004). Thus, ERK signaling may also be important for C-R cell generation. To identify whether ERK activity may regulate Reelin production or $\mathrm{C}-\mathrm{R}$ cell maintenance, we examined C-R cells
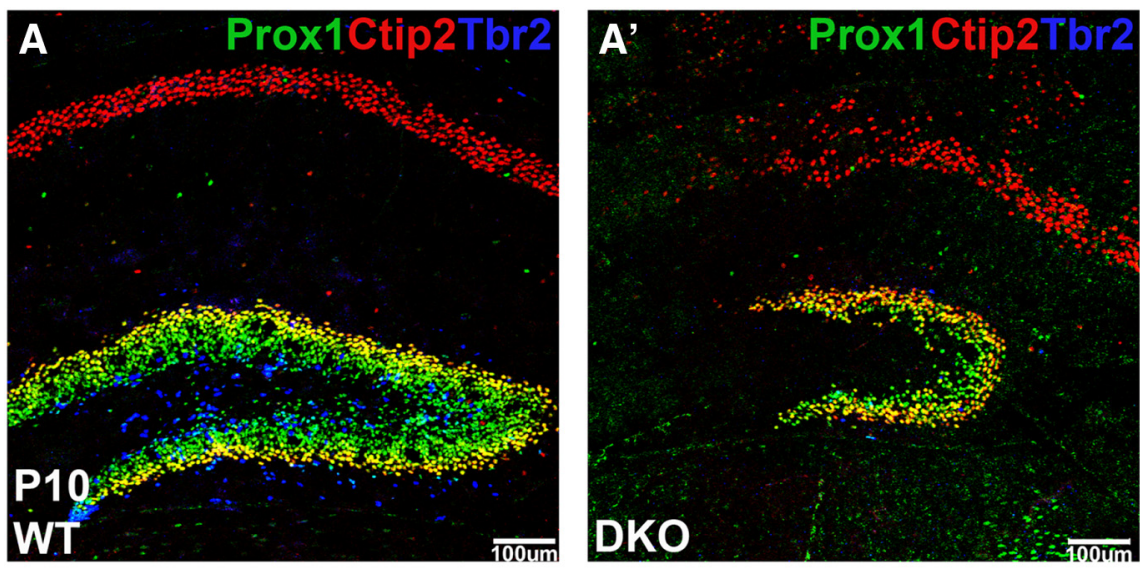

B

P10 DG Granule Cells
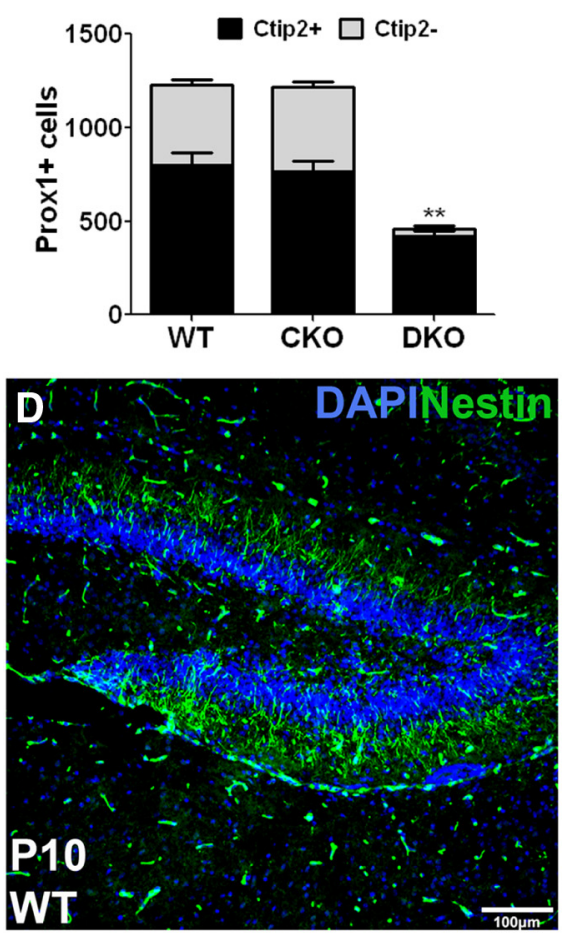

C
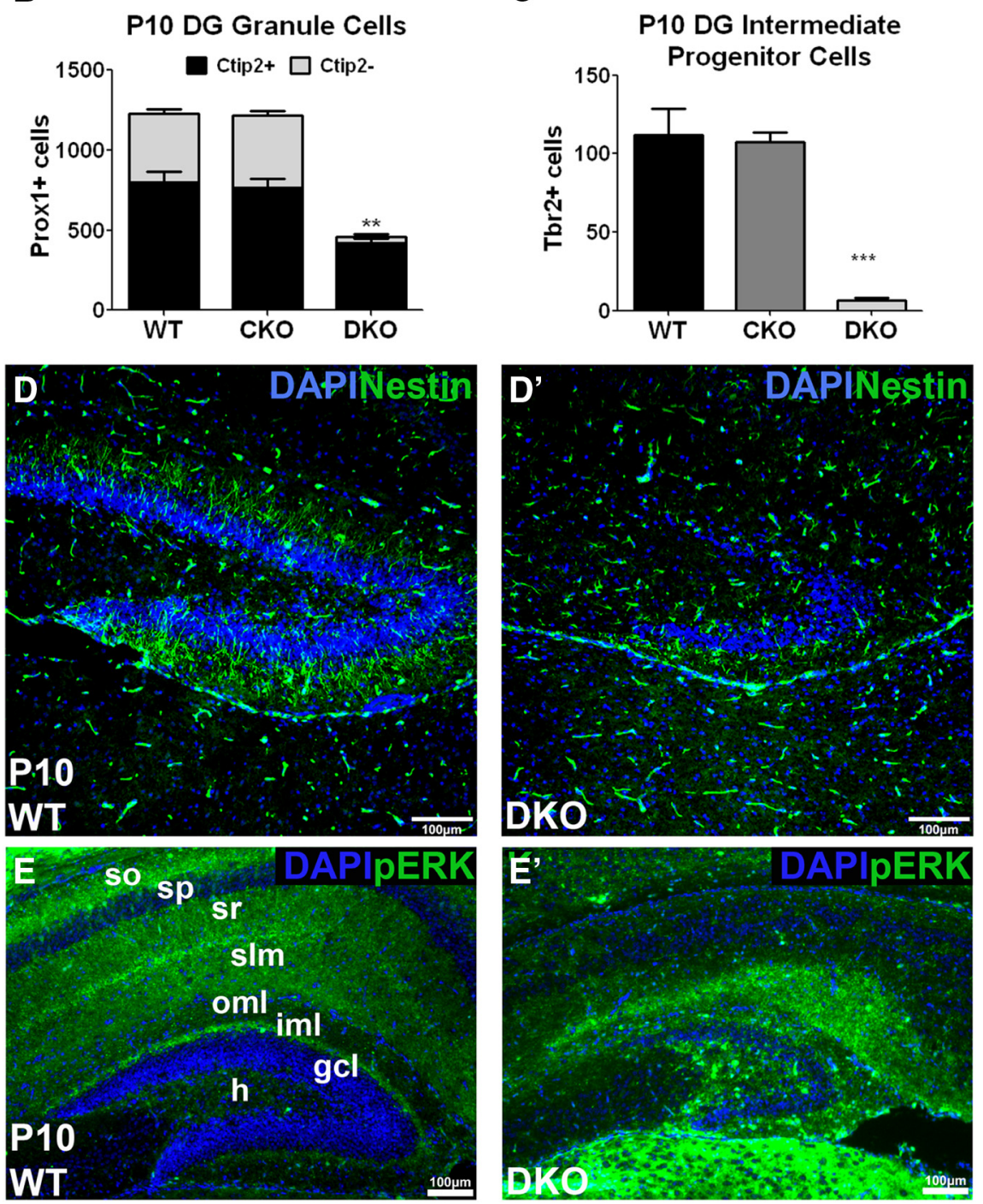

Figure 3. DK0 mice exhibit severe hippocampal hypoplasia with near complete loss of neural progenitors in the $D G . A, A^{\prime}$, IHC of Prox 1 (green), Ctip2 (red), and Tbr2 (blue) in the hippocampus ofWT ( $\boldsymbol{A}$ ) and DKO (B) mice at P10. Scale bar, $100 \mu \mathrm{m}$. $\boldsymbol{B}$, Quantification of Prox1 cells in the DG ofWT,CKO, and DKO mice. ${ }^{* *} p=0.0012$ (ttest). Mean \pm SEM:WT: $1227 \pm 93.41, N=4 ; C K 0: 1218 \pm 77.06, N=4 ;$ DKO: $460.8 \pm 40.34, N=3$. Prox $^{+}{ }^{+}$granule cells were stratified into mature Ctip2 ${ }^{+}$granule cells (black bar) and immature Ctip2 ${ }^{-}$granule cells (gray bar). Ctip2 ${ }^{+}$cells, WT: 797.2 $\pm 69.61, N=4 ;$ CKO: 762.7 $\pm 58.85, N=4 ;$ DK0: $419.2 \pm 25.92, N=3$. Ctip2 ${ }^{-}$cells, WT: $429.5 \pm 29.57, N=4 ;$; CKO: 455.5 $\pm 25.36, N=4 ;$ DKO: $41.67 \pm 14.42, N=3$. C, Quantification of Tbr2 ${ }^{+}$IPCsin the DG ofWT, CKO, and DKO mice. ${ }^{* * *} p=0.0001$ (ttest). Mean \pm SEM:WT: $112.0 \pm 16.69, N=4 ;$; CKO: $107.6 \pm 5.931, N=4 ;$ DKO: $6.625 \pm 1.772, N=4 . D$, $\boldsymbol{D}^{\prime}$, Immunostaining for Nestin ${ }^{+}$cells (green) in the DG of P10 WT and DKO mice. Scale bar, $100 \mu \mathrm{m} . \boldsymbol{E}, \boldsymbol{E}^{\prime}$, Immunostaining for pERK (green) and DAPI (blue) in theP10 hippocampus ofWT $(E)$ and DKO $\left(E^{\prime}\right)$ mice. So, Stratum oriens; 5 , stratum pyramidale;sr, stratum radiatum; slm, stratum lacunosum molecular; oml, outer molecular layer; iml, inner molecular layer; gd, granule cell layer; h, hilus. Scale bar, $100 \mu \mathrm{m}$. 

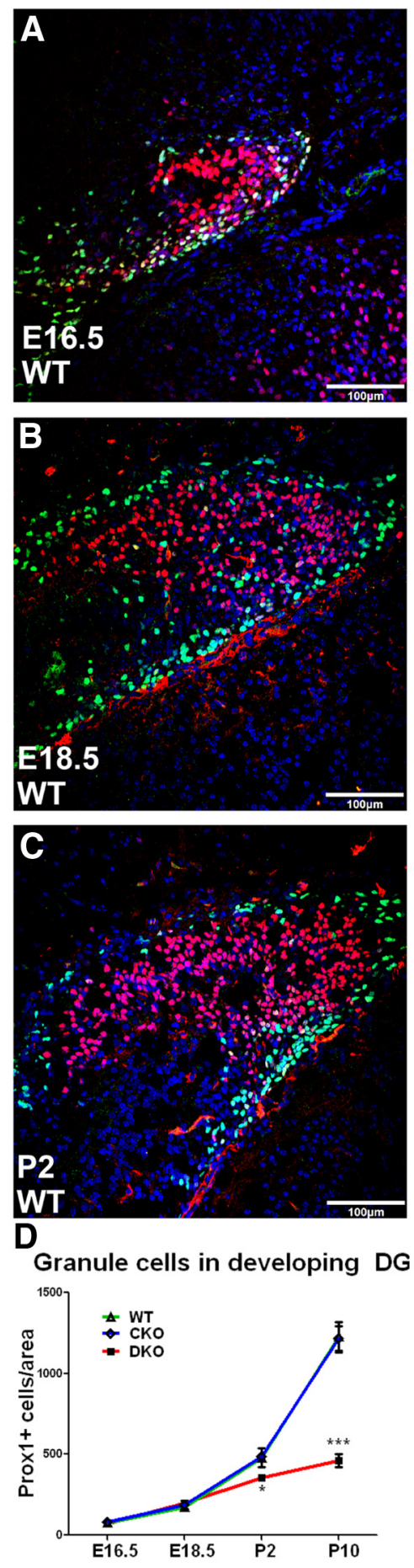

ए
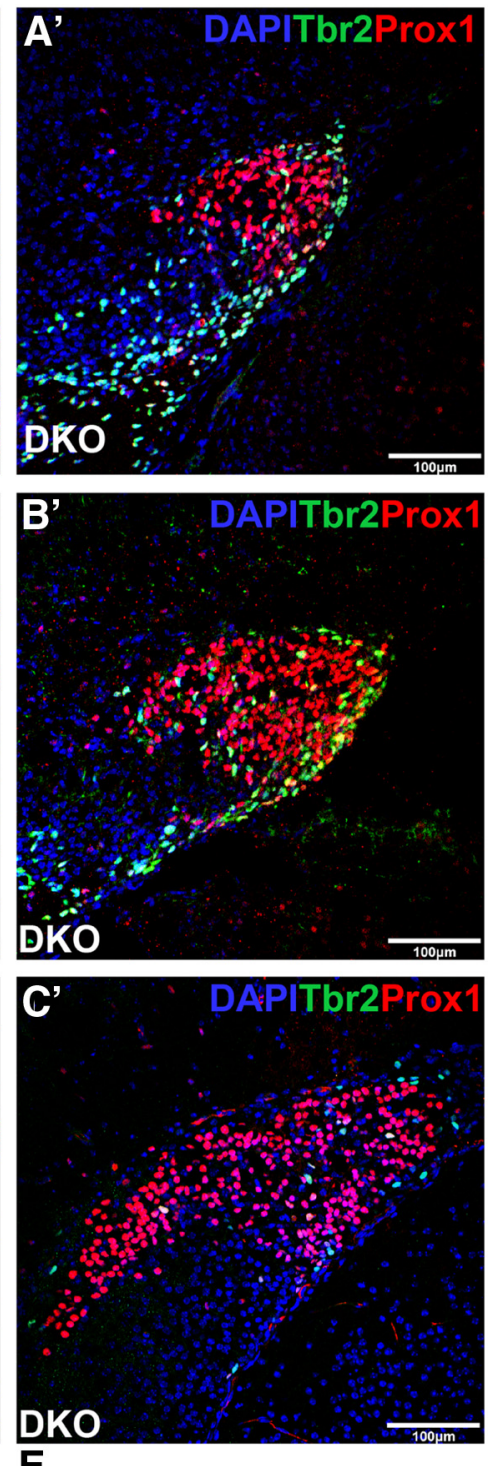

IPCs in developing DG
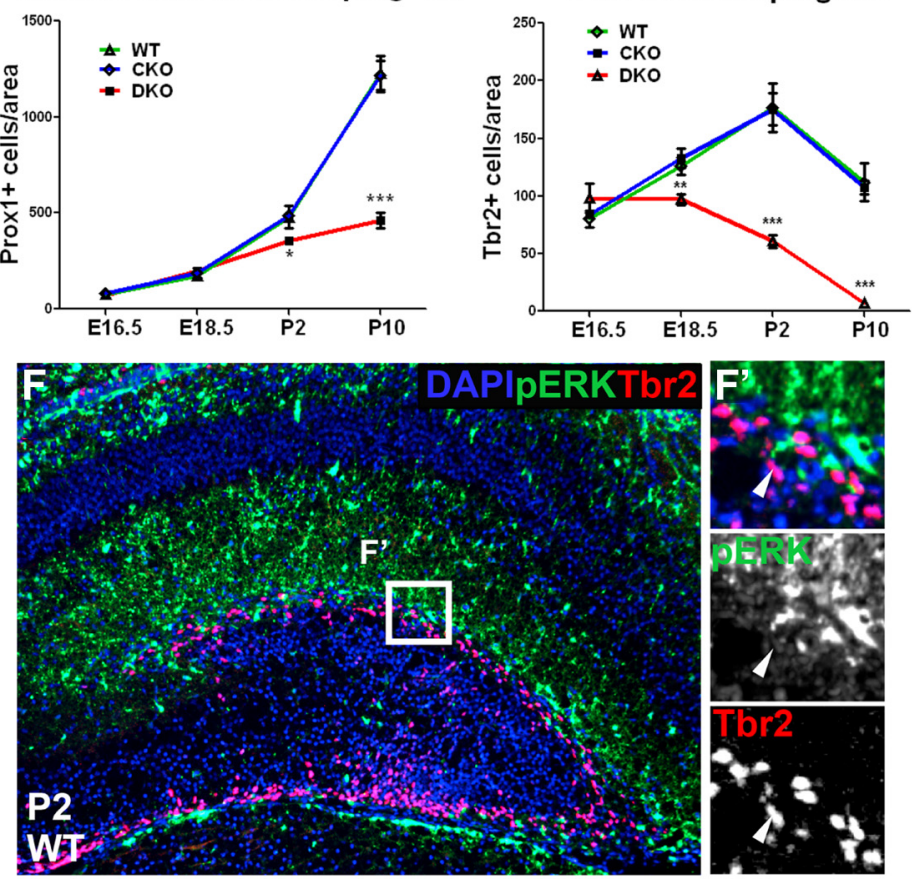

for phospho-ERK immunoreactivity by immunostaining E16.5 and P2 tissue for phospho-ERK and p73, a marker for C-R cells (Fig. 7A-D). We observed colocalization of phospho-ERK and p73 immunoreactivity in a subset of $\mathrm{p} 73^{+} \mathrm{C}-\mathrm{R}$ cells at E16.5 and P2 in WT mice (Fig. $7 A, C^{\prime}$ ). Interestingly, some $\mathrm{C}-\mathrm{R}$ cells in the $\mathrm{DKO}$ expressed phospho-ERK as well, indicating that some of these C-R cells were not Emx1 derived (Fig. $7 B, D^{\prime}$ ).

We observed no difference in C-R cells in the DG at E16.5, which we assessed by counting $73^{+}$cells (Fig. 7E). However, by $\mathrm{P} 2$ we observed a $32 \%$ reduction in $\mathrm{C}-\mathrm{R}$ cells in the hippocampus of DKO mice $(t$ test, $p=0.0072$ ) (Fig. $7 E$ ). Additionally, we examined Reelin levels by Western blot analysis in the hippocampus of $\mathrm{P} 2$ mice. Consistent with the decrease in C-R cells, we observed a $23 \%$ decrease in Reelin in the DKO mice at P2 ( $t$ test, $p=0.0176$ ) (Fig. $7 F$ ). These data indicate that early presence of C-R cells is not affected by loss of ERK1/2 signaling, but by $\mathrm{P} 2$ there is a significant decrease in the number of C-R cells, which may contribute to the phenotype of the DG.

Wnt signaling is not affected by loss of ERK1/2

Wnt signaling has previously been shown to be a critical regulator of DG development by regulating proliferation and differentiation of radial glial cells (Lee et al., 2000; Kim et al., 2001; Yoshinaga et al., 2010). Wnt signaling forms a reciprocal gradient with FGF signaling in the devel-

$\leftarrow$

Figure 4. Loss of ERK1/2 signaling causes progressive depletion of $\mathrm{Tbr}{ }^{+} \mathrm{IPCs}$ and decreased generation of Prox ${ }^{+}$ granule cells during DG development. $\boldsymbol{A}-\boldsymbol{C}, \boldsymbol{A}^{\prime}-\boldsymbol{C}^{\prime}$, Immunostaining for Prox ${ }^{+}$(red) and $\mathrm{Tbr}^{+}$(green) cells in the $\mathrm{DG}$ of WT $(\boldsymbol{A}-\boldsymbol{C})$ and DKO $\left(\boldsymbol{A}^{\prime}-\boldsymbol{C}^{\prime}\right)$ mice at E16.5 $\left(\boldsymbol{A}, \boldsymbol{A}^{\prime}\right)$, E18.5 $(\boldsymbol{B}$, $\left.\boldsymbol{B}^{\prime}\right)$, and P2 $\left(\boldsymbol{C}, \boldsymbol{C}^{\prime}\right)$. Scale bar, $100 \mu \mathrm{m}$. D, Quantification of Prox ${ }^{+}$granule cells in the developing DG at E16.5, E18.5, P2, and P10. ${ }^{*} p=0.0495$ ( $t$ test). ${ }^{* *} p=0.0012$ ( $t$ test). Mean \pm SEM: E16.5, WT: $76.66 \pm 2.642, N=4$; CKO: $82.75 \pm 5.034$, $N=6$; DK0: $74.13 \pm 5.085, N=7$. E18.5, WT: $189.3 \pm$ 21.99, $N=4 ;$ CKO: $196.7 \pm 20.27, N=4$; DKO: $201.0 \pm$ 5.395, $N=5$. P2, WT: $477.5 \pm 58.48, N=4$; CKO: 487.1 $\pm 14.69, N=4 ;$ DKO: $356.9 \pm 19.31, N=6 . P 10:$ data from Figure 2. $E$, Quantification of Tbr2 ${ }^{+}$IPCs in DG at E16.5, E18.5, $\mathrm{P} 2$, and P10. ${ }^{* *} p=0.0014$ ( $t$ test). ${ }^{* * *} p<0.0001$ ( $t$ test). Mean \pm SEM: E16.5, WT: $76.62 \pm 5.533, N=7$; CKO: $77.65 \pm 2.087, N=9 ;$ DKO: $120.4 \pm 10.89, N=5$. E18.5, WT: $137.2 \pm 5.651, N=3$; CKO: $121.3 \pm 6.93, N=3$; DKO: $96.86 \pm 4.876, N=7$. P2, WT: $176.7 \pm 20.71, N=5$; CKO: $175.1 \pm 14.06, N=5 ;$ DKO: $60.58 \pm 5.223, N=12$. P10: data from Figure 2. $\boldsymbol{F}, \boldsymbol{F}^{\prime}$, Immunostaining of phospho-ERK (green) and Tbr2 (red) with DAPI (blue) in the hippocampus of P2WT mice. $\boldsymbol{F}^{\prime}$, Magnification of the box in $\boldsymbol{F}$, with arrowheads indicating a Tbr2 ${ }^{+}$cell. 

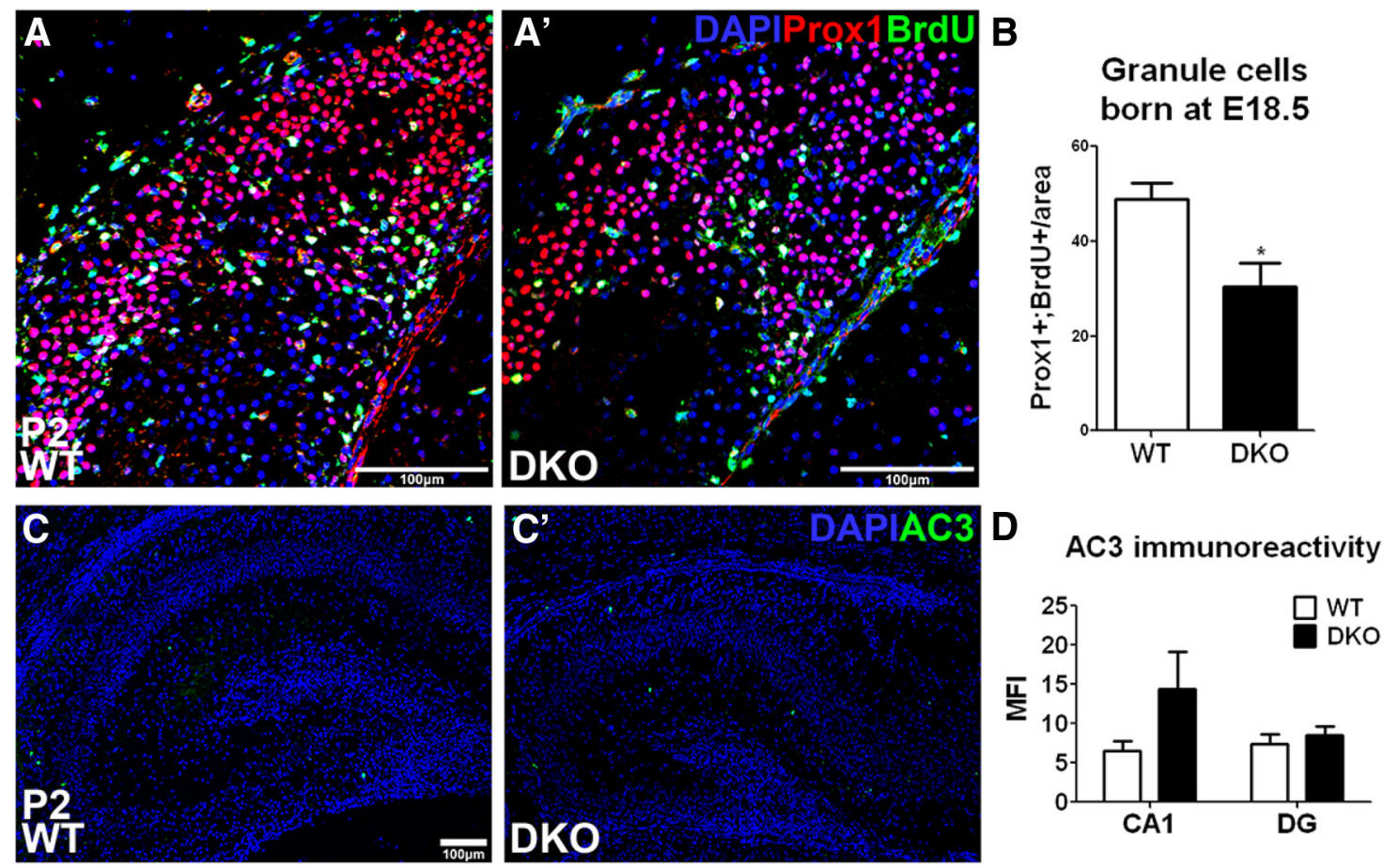

Figure 5. Generation of granule cells is impaired in ERK1/2 DK0 mice. $A, A^{\prime}$, Immunostaining for BrdU ${ }^{+}$(green) and Prox $1^{+}$(red) cells in P2 mice treated with BrdU at E18.5. Scale bar, $100 \mu \mathrm{m}$. $B$, Quantification of Prox ${ }^{+}, \mathrm{BrdU}^{+}$-colabeled granule cells in P2 mice identifying granule cells born at E18.5. ${ }^{*} p=0.024$ ( $t$ test). Mean \pm SEM: WT: 48.89 $\pm 3.466, N=3 ;$ DK0: $30.33 \pm 5.153$, $N=4$. C, $\boldsymbol{C}^{\prime}, \boldsymbol{D}$, Activated Caspase 3 (green) immunostaining identifying apoptotic cells in P2 (D, $\left.\boldsymbol{D}^{\prime}\right)$ hippocampus from WT $(\boldsymbol{C})$ and DKO $\left(\boldsymbol{C}^{\prime}\right)$ mice. Scale bar, $100 \mu \mathrm{m}$. Quantification of mean fluorescent intensity (MFI) (D). Mean \pm SEM: CA1, WT: $6.523 \pm 1.294, N=4$; DK0: $14.36 \pm 4.792, N=4$. DG, WT: $7.346 \pm 1.358, N=4 ;$ DK0: $8.514 \pm 1.16, N=4$.

oping telencephalon, which can be observed as early as E11.5 (Shimogori et al., 2004). Interestingly, FGF8 overexpression drives rostral patterning and represses Wnt signaling (Kuschel et al., 2003; Shimogori et al., 2004). These pathway interactions drive the patterning of the dorsal telencephalon. Whether this repression is ERK dependent is still unknown, raising the possibility that the developmental perturbations to the DG in DKO mice are a result of altered Wnt signaling. To determine whether loss of ERK signaling affects Wnt signaling, GSK $3 \beta$ activity in the telencephalon was evaluated by Western analysis at E14.5 and at P2 (Fig. $8 A-C$ ). GSK3 $\beta$ is phosphorylated on Ser9, which allows $\beta$-catenin translocation to the nucleus and subsequent transcription of target genes, including Axin2. Ser9 phosphorylation of GSK3 $\beta$ was not altered in DKO or CKO mice at E14.5 or P2 (Fig. $8 A$ ). $\beta$-Catenin and Axin2 levels were unchanged as well (Fig. $8 B, C)$. Although nuclear translocation of $\beta$-catenin is the critical determinant for canonical Wnt signaling transduction, the fact that phospho-GSK3 $\beta$ and Axin2 levels are not significantly altered suggests that $\beta$-catenin localization is not altered either. Finally, in situ hybridization analysis of Wnt3a expression at E13.5 showed that DKO mice expressed Wnt3a at levels comparable with WT (Fig. $8 D, D^{\prime}$ ). These data indicate that the Wnt signaling was not altered by loss of both ERK1 and ERK2 levels.

\section{Discussion}

Mutations in various elements of the MAPK/ERK pathway cause a collection of disorders known as NCFC syndromes, which are characterized by multiple overlapping phenotypes, including intellectual disability (Samuels et al., 2009). Identifying the specific roles of ERK1/2 activity during brain development may provide critical insight into the pathogenesis of cognitive impairment in NCFC syndromes and other RASopathies. Of particular interest is the hippocampus, where ERK signaling has been shown to play a critical role in regulating synaptic plasticity and memory formation (Thomas and Huganir, 2004). Our studies establish that ERK1/2 signaling is necessary for normal development of the hippocampus.

Complete loss of ERK1/2 signaling causes progressive decline in Pax6 ${ }^{+}$radial glial cells and Tbr2 ${ }^{+}$neuronal IPCs in the developing DG. The resulting depletion of progenitors prevents expansion and generation of granule cells in the DG during the first postnatal week. The decline in progenitor populations is not due to cell death and likely due to progenitors undergoing neurogenic rather than proliferative divisions, which deplete progenitor pools in the developing DG. This effect on progenitor pools results in a significantly smaller and dysmorphic DG in the DKO mice. Surprisingly, loss of ERK2 alone does not impair development of the hippocampus, indicating that the presence of either isoform is sufficient for normal hippocampal development (Selcher et al., 2001; Mazzucchelli et al., 2002).

The loss of ERK1/2 signaling has a more striking effect on progenitors in the tertiary dentate matrix, the developing DG proper, compared with the VZ of the DG. One explanation is impaired migration of radial glia into the DG. Radial glia migrate from the VZ of the DG through the DMS and into the DG, in the process forming the three germinal matrices of the DG (Rickmann et al., 1987; Altman and Bayer, 1990; Li et al., 2009). As DG development advances, the radial glia in these secondary and tertiary germinal zones become the primary neurogenic zones and form scaffolding required for the formation of the two blades of the DG (Frotscher et al., 2003; Sibbe et al., 2009). Radial glia in the VZ may not be able to translocate to the DG in DKO mice and thus more significantly impact progenitors in the DG. However, we did not observe evidence of impaired migration, such as ectopic neurons in the VZ or DMS. The most parsimonious explanation of our findings is that ERK $1 / 2$ is required for maintaining the 


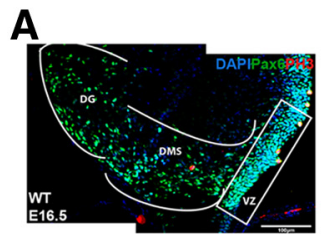

A'
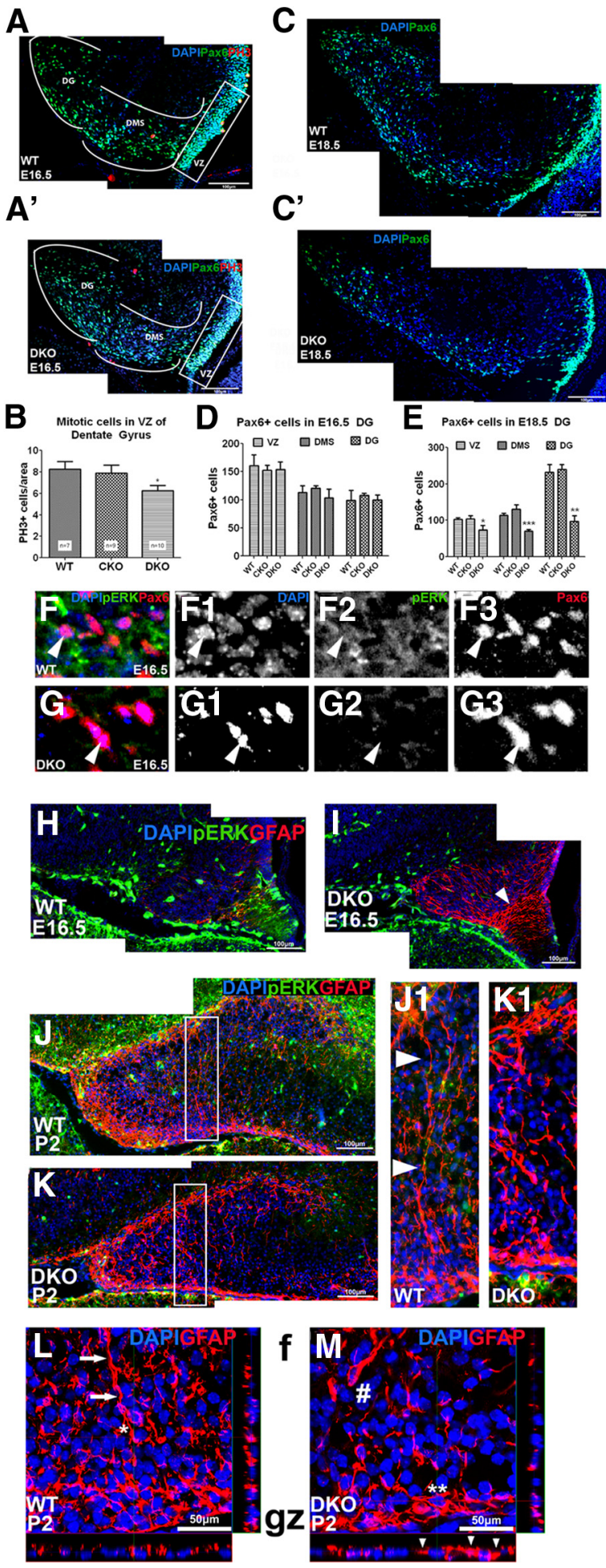

Figure 6. Loss of ERK1/2 signaling causes a decline in VZ mitotic activity and depletion of radial glial cells in the developing DG. $\boldsymbol{A}, \boldsymbol{A}^{\prime}$, Immunostaining for Pax6 (green) and phospho-H3 (red) in E16.5 WT and DKO mice. Scale bar, $100 \mu \mathrm{m}$. B, Quantification of phospho-H3 ${ }^{+}$cells in the dentate VZ ofE16.5WT, CKO, and DKO mice. ${ }^{*} p=0.024$ ( $t$ test). Mean \pm SEM:WT: $8.274 \pm$ $0.7017, N=7 ;$ CK0: $7.870 \pm 0.7421, N=9$; DK0: $6.267 \pm 0.4574, N=10 . C_{,} C^{\prime}$, Immunostaining for Pax6 (green) in E18.5 WT and DKO mice. Scale bar, $100 \mu \mathrm{m}$. D, Quantification of Pax6 $^{+}$cells in the DG, DMS, and VZ of E16.5 WT, CKO, and DKO mice. Mean \pm SEM: VZ, WT: $160.9 \pm 19.29, N=3$; CKO: $152.2 \pm 9.09, N=4$; DK0: $153.7 \pm 14.03, N=5$. DMS, WT: $113.3 \pm 11.46, N=3$; CKO: $120.4 \pm 4.77, N=4 ;$ DKO: $103.7 \pm 15.23, N=5$. DG, WT: $99.28 \pm 17.91, N=3$; CK0: $108.3 \pm 3.17, N=4$; DKO: $99.80 \pm 9.18, N=5 . \boldsymbol{E}$, Quantification of Pax6 ${ }^{+}$cells in the DG, DMS, and VZ of E18.5 WT, CKO, and DKO mice. ${ }^{*} p=0.03$ ( $t$ test). ${ }^{* * *} p=0.0009$ (ttest). ${ }^{* *} p=0.0017$ (ttest). Mean \pm SEM:VZ,WT:102.4 $\pm 4.35, N=6 ;$ CKO: radial glial population that migrate into the DG from the VZ. Based on our findings, ERK1/2 signaling is more important in maintaining neural progenitors in the DMS and DG than in the VZ. The loss of ERK1/2 signaling leads to decreased proliferation and precocious maturation of radial glia, which depletes the DG of progenitors in the tertiary germinal zone. Interestingly, hyperactivation of MEK $1 / 2$ leads to excessive gliogenesis at the expense of neurogenesis (Li et al., 2012). Thus, the increase in MEK activity in the ERK1/2 DKO mice may contribute to the precocious radial glial maturation through ERK1/2 independent mechanisms.

The most striking effect we observed was the significant decline in Tbr $2^{+}$IPCs during development of the DG. Compared with the DG morphology of Tbr2 KO mice, we observed slightly attenuated effects in the ERK1/2 DKO mice. Tbr2 KO mice exhibit a significant reduction in granule cells with impaired migration of C-R cells, both of which are derived from Tbr2 ${ }^{+}$IPCs. Additionally, the DG was severely dysmorphic due to impaired hippocampal fissure formation, resulting in a small suprapyramidal blade and absent infrapyramidal blade (Hodge et al., 2013) . In the DKO mice we examined, the DG formed two blades, and we did not observe any C-R cell migration defects. However, C-R cells and Reelin levels were decreased in the P2 hippocampus. $\mathrm{C}-\mathrm{R}$ cell migration occurs along the meninges using chemotactic cues that are present in the meninges as well as the end-feet of radial glial cells (Borrell and Marín, 2006; Kwon et al., 2011). Although migration of C-R cells was not affected in DKO mice, their recruitment in the postnatal hippocampus may be decreased due to depletion of the progenitor populations. It is possible that the depletion of progenitors in the DG of DKO mice causes a reduction in $\mathrm{C}-\mathrm{R}$ cells due to a reduced requirement for $\mathrm{C}-\mathrm{R}$ cells. Expression of Reelin by C-R cells around the hippocampal fissure is also important for hippocampal circuit formation because Reelin regulates CA1 pyramidal neuron migration and lamination as well as the entorhinal axonal projections to the DG (Del Río et al., 1997; Borrell et al., 1999). These neuronal populations, which are also affected in DKO mice, could also regulate C-R cell recruitment Alternatively, ERK signaling could directly impair C-R cell generation and Reelin signaling. However, at E16.5, we did not observe an effect on C-R cells, which are first generated around E10.5 (Bielle et al., 2005). In addition, mouse models of impaired Reelin signaling have more severe phenotypes showing migration deficits and ectopic cells (Stanfield and Cowan, 1979; Grant et al., 1992). Loss of Reelin also affects the radial glial scaffold, resulting in an absence of the two blades of the DG (Brunne et al., 2013). Although we did not observe any ectopic cells in the DKO DG, the change in the radial glial scaffold could be attributed to decreased Reelin levels and may contribute to the altered shape of the DG.

An interesting issue these data raise centers around the cellautonomous and non-cell-autonomous roles for ERK signaling.

$103.7 \pm 9.60, N=5 ;$ DKO: $74.28 \pm 11.62, N=4$. DMS, WT: $113.6 \pm 6.11, N=6 ;$ CKO $130.3 \pm 12.23, N=5 ;$ DKO: $70.2 \pm 4.51, N=4 . D G$, WT:232.6 $\pm 21.06, N=6 ; C K 0: 240.3 \pm$ $13.57, N=5 ;$ DK0: $97.6 \pm 15.73, N=4 . F, G$, Immunostaining of phospho-ERK (green) (F2, $\boldsymbol{G 2}$ ), and Pax6 (red) $(\boldsymbol{F 3}, \mathbf{G 3})$, with DAPI (blue) $(\boldsymbol{F 1}, \boldsymbol{G} \mathbf{)})$ in the DG proper in WT $(\boldsymbol{F})$ and DKO (G) mice at E16.5. $\boldsymbol{H}-\boldsymbol{K}$, Immunostaining of phosphor-ERK (green), GFAP (red), and DAPI (blue) in the hippocampus of WT $(\boldsymbol{H}, \boldsymbol{J})$ and DKO $(\boldsymbol{I}, \boldsymbol{K})$ mice at E16.5 $(\boldsymbol{H}, \boldsymbol{I})$ and P2 $(\boldsymbol{J}, \boldsymbol{K}) . \boldsymbol{J}, \boldsymbol{K}$, Rectangles are enlarged in $\boldsymbol{J}$ and $\boldsymbol{K} \mathbf{1}$, with arrowheads indicating radial glial process extending through DG. $L, M$, Immunostaining of GFAP (red) and DAPI (blue) in the tertiary germinal zone ( $\mathrm{gz}$ ) in WT and DKO mice. $L$, WT mice exhibits GFAP ${ }^{+}$cells $\left(^{*}\right)$ with radial process (arrows) extending to the fissure (f). $M$, DKO mice exhibit multiple GFAP ${ }^{+}$cells $\left(\#,{ }^{* *}\right)$ with horizontal processes (arrowheads in $z$-plane correspond to cell marked by **). 

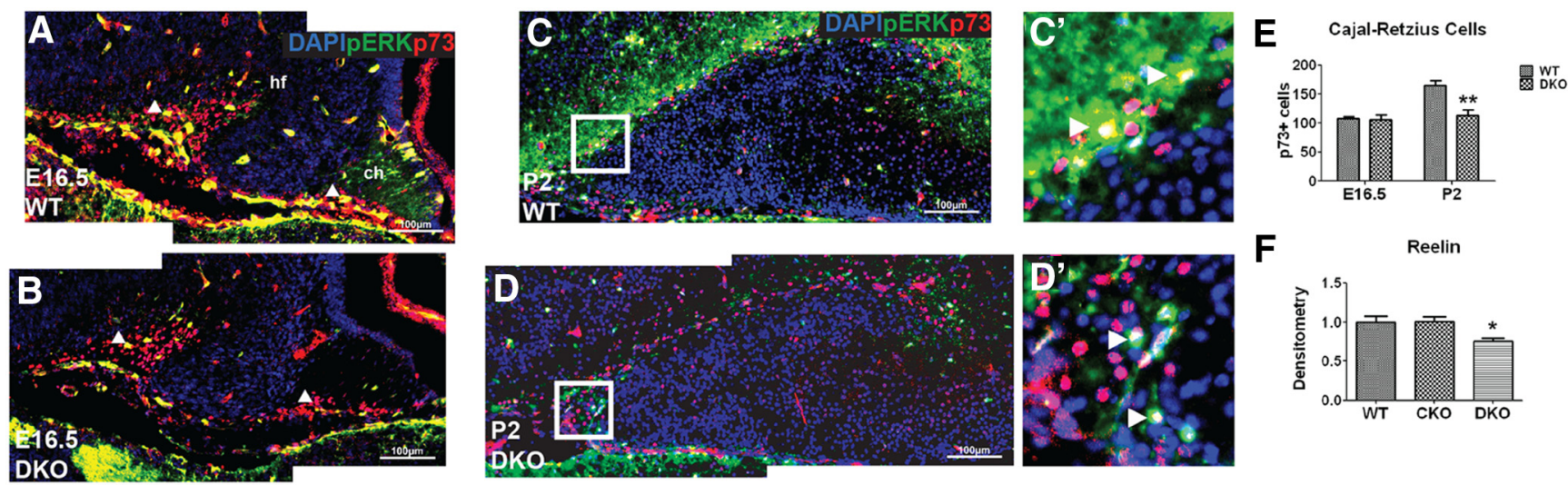

Figure 7. C-R cells and Reelin expression are decreased in ERK1/2 DKO mice at P2. A-D, IHC of phospho-ERK (green), p73 (red), and DAPI (blue) in the DG of E16.5 and P2 WT (A, C) and DKO ( $\boldsymbol{B}$, D) mice. hf, Hippocampal fissure; ch, cortical hem. $\boldsymbol{C}^{\prime}, \boldsymbol{D}^{\prime}$, Enlarged insets with arrowheads showing colocalization of phospho-ERK and p73. Scale bar, $100 \mu \mathrm{m}$. $\boldsymbol{E}$, Quantification of p73 ${ }^{+}$cells in the DG of E16.5 and P2 WT and DKO mice. ${ }^{* *} p=0.0072$ ( $t$ test). Mean \pm SEM: E16.5, WT: $108.0 \pm 3.439, N=5 ;$ DKO: $105.9 \pm 8.053, N=4$. P2, WT: 165.5 $\pm 7.631, N=4 ;$ DKO: 112.7 \pm 10.83 , $N=4$. F, Quantification of Western blot of Reelin protein in the hippocampus of P2 WT and DKO mice. ${ }^{*} p=0.0176$ ( $t$ test). Mean \pm SEM: WT: 1.079 $\pm 0.052, N=4 ;$ CKO: $1.005 \pm 0.041, N=$ 5; DKO: $0.8356 \pm 0.0389, N=3$.
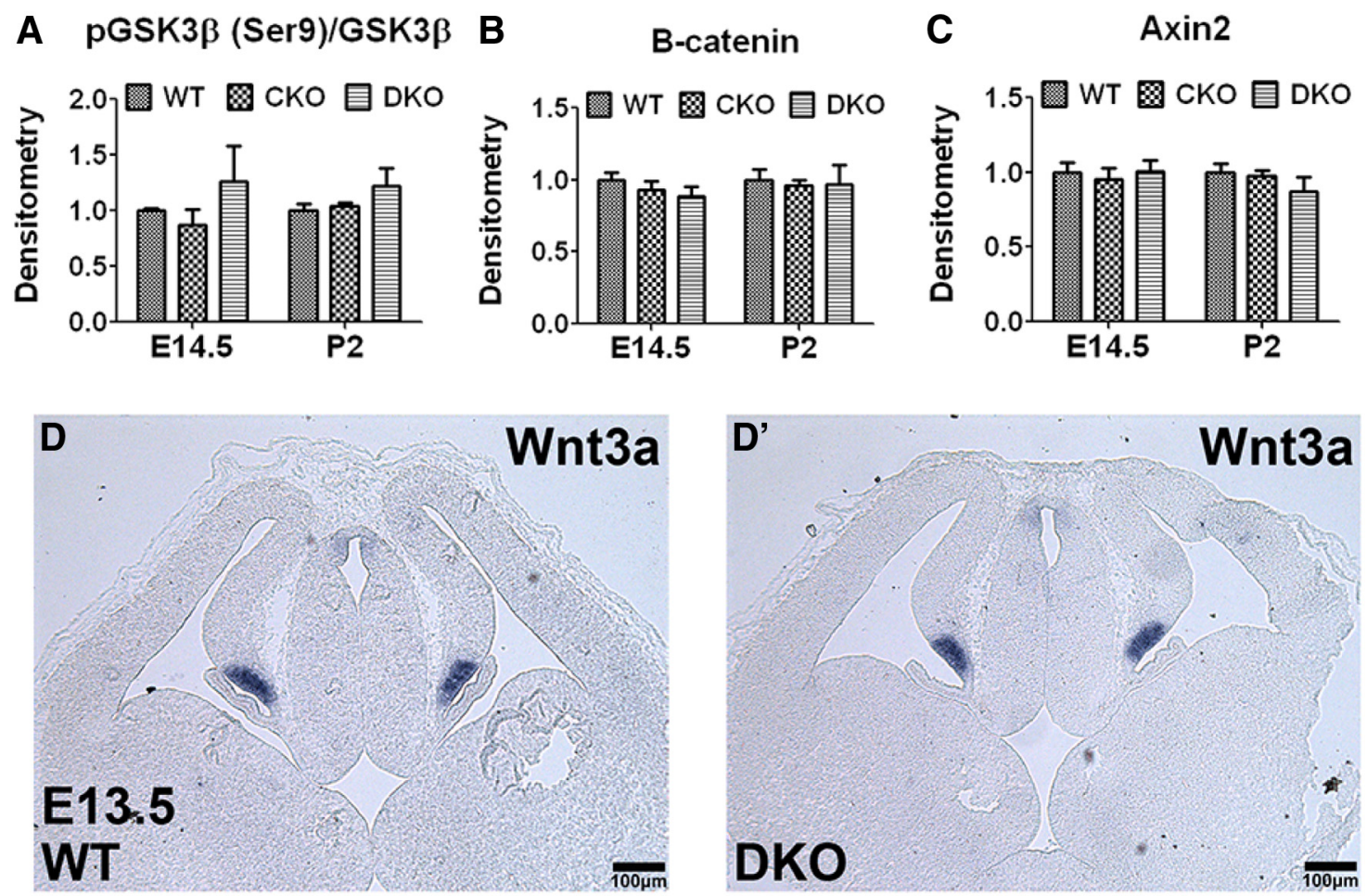

Figure 8. Loss of ERK1/2 signaling does not affect Wnt signaling in the developing hippocampus. $A$, Western analysis of GSK3 $\beta$ Ser9 phosphorylation in E14.5 and P2 WT, CK0, and DK0 mice (normalized to total GSK3 $\beta$ ). Mean \pm SEM:E14.5, WT: $1.000 \pm 0.02650, N=5 ;(K 0: 0.8695 \pm 0.1378, N=9 ;$ DKO: $1.266 \pm 0.3191, N=9 . P 2, W T: 1.000 \pm 0.057, N=5 ;$ CKO: 1.039 \pm 0.0366 , $N=5 ;$ DKO: $1.220 \pm 0.157, N=3 . B$, Western analysis of B-catenin in E14.5 and P2 WT, CKO, and DKO mice (normalized to actin). Mean \pm SEM: E14.5, WT: 1.000 $\pm 0.05465, N=10 ;$ CKO: $0.9325 \pm 0.05769, N=11 ; \mathrm{DK} 0: 0.8862 \pm 0.06922, N=11 . P 2, \mathrm{WT}: 1.000 \pm 0.0769, N=5 ; C K 0: 0.9590 \pm 0.0409, N=5 ; \mathrm{DKO} 0: 0.9698 \pm 0.1336, N=3$. C, Axin2 Western blot analysis in E14.5 and P2 WT, CKO, and DKO mice (normalized to actin). Mean \pm SEM:E14.5, WT:1.000 $\pm 0.06493, N=10 ; C K 0: 0.9509 \pm 0.07756, N=11 ; D K 0: 1.005 \pm 0.07825, N=11 . P 2, W T: 1.000 \pm 0.0573$, $N=5 ; C K 0: 0.9729 \pm 0.0396, N=5 ;$ DK0:0.8726 $\pm 0.0937, N=3 . D, D^{\prime}$, In situ hybridization of Wnt3a in WT and DK0 mice at E13.5. DK0 mice show no change in Wnt3a mRNA levels compared with WT. Scale bar, $100 \mu \mathrm{m}$.

The presence of phospho-ERK in Nestin ${ }^{+}$radial glial cells in the dentate VZ suggests cell-autonomous functions for ERK signaling in radial glial cell maintenance. However, the timing of depletion of progenitors begins at E18.5, and the most significant effects occur between E18.5 and P10. During this time, phosphoERK expression is found in C-R cells and the SLM/SR of the CA1 in both $\mathrm{Nestin}^{+}$radial glial cells and Tuj $1^{+}$postmitotic neurons. This may also indicate non-cell-autonomous roles, where ERK signaling in radial glial cells and neuronal projections to the DG participates in the maintenance of neural progenitors in the DG and thus regulates granule cell population.

These observations are generally consistent with the role of ERK signaling during cortical development. Loss of ERK2 in the telencephalon causes precocious neurogenesis in the cortex, resulting in cytoarchitectural changes (Satoh et al., 2007; Imamura et al., 2010; Pucilowska et al., 2012). However, we did not observe any changes in the hippocampus in the ERK2 CKO mice. In examining the level of phosphorylated ERK in the telencephalon, 
we found that it is more concentrated in the VZs of the cortex compared with the VZs of the hippocampus. We also observed that neural progenitor populations in the developing DG express phospho-ERK at much lower levels compared with other cell types. These data indicate that loss of ERK2 alone does not affect hippocampal development because ERK1 is sufficient for development, indicating that there are no apparent isoform-specific actions of ERK1 and ERK2 developmentally. However, in the cortex, the requirement for ERK signaling is much greater and ERK1 alone cannot compensate for the loss of ERK2.

Interestingly, FGF8 hypomorphic mice and FGFR1/2/3 triple mutant mice have more severe phenotypes than the DKO mice, which highlight the importance of other pathways downstream of FGFRs that mediate neurogenesis (Storm et al., 2006; Paek et al., 2009). Importantly, to confirm that the loss of ERK signaling was directly responsible for perturbing hippocampal development, we show that the impaired development of the hippocampus was not secondary to changes in Wnt signaling, which has previously been shown to play a critical role in hippocampal morphogenesis (Li and Pleasure, 2007). Our data also indicate that the reciprocal repression between FGF8 and Wnt signaling is not ERK dependent at the time points we studied.

Additionally, we examined how ERK signaling regulates the negative feedback loops of the MAPK pathway. The MAPK pathway is precisely regulated through various feedback mechanisms that tightly control activation of the Raf and MEK kinases (Hanafusa et al., 2002; Dougherty et al., 2005; Catalanotti et al., 2009). Surprisingly, our results show that very little ERK signaling is required for normal negative feedback regulation of the ERK MAPK pathway, as loss of ERK2 alone does not significantly dysregulate the ERKMAPK pathway. This was a particularly interesting finding because ERK2 is present at much higher levels than ERK1 in the brain (Ortiz et al., 1995). The feedback signal is not ERK1 dependent as loss of ERK1 does not cause significant dysregulation of the MAPK pathway (Mazzucchelli et al., 2002). However, loss of both ERK1 and ERK2 causes massive upregulation in MEK signaling, indicating that MEK-targeted feedback by ERK1/2 is not gene dose-dependent. Instead, it appears that there is a modest threshold of ERK expression required to inhibit MEK activation. Furthermore, either ERK1 or ERK2 is sufficient to regulate feedback of the MAPK pathway.

In conclusion, ERK signaling plays a vital role during granule cell neurogenesis. The functions of ERK signaling in the hippocampus are more pronounced later in development when granule cell production peaks. Furthermore, because loss of only ERK2 affects the development of the cortex, but not hippocampus, the data also highlight the fact that the levels of ERK signaling needed for neurogenesis are spatially and temporally distinct.

\section{References}

Abraham H, Pérez-García CG, Meyer G (2004) p73 and reelin in CajalRetzius cells of the developing human hippocampal formation. Cereb Cortex 14:484-495. CrossRef Medline

Adviento B, Corbin IL, Widjaja F, Desachy G, Enrique N, Rosser T, Risi S, Marco EJ, Hendren RL, Bearden CE, Rauen KA, Weiss LA (2014) Autism traits in the RASopathies. J Med Genet 51:10-20. CrossRef Medline

Altman J, Bayer SA (1990) Migration and distribution of two populations of hippocampal granule cell precursors during the perinatal and postnatal periods. J Comput Neurol 301:365-381. CrossRef Medline

Arnold SJ, Huang GJ, Cheung AF, Era T, Nishikawa S, Bikoff EK, Molnár Z, Robertson EJ, Groszer M (2008) The T-box transcription factor Eomes/ Tbr2 regulates neurogenesis in the cortical subventricular zone. Genes Dev 22:2479-2484. CrossRef Medline

Barry G, Piper M, Lindwall C, Moldrich R, Mason S, Little E, Sarkar A, Tole S, Gronostajski RM, Richards LJ (2008) Specific glial populations regulate hippocampal morphogenesis. J Neurosci 28:12328-12340. CrossRef Medline
Bayer SA, Altman J (1990) Development of layer I and the subplate in the rat neocortex. Exp Neurol 107:48-62. CrossRef Medline

Bentires-Alj M, Kontaridis MI, Neel BG (2006) Stops along the RAS pathway in human genetic disease. Nat Med 12:283-285. CrossRef Medline

Bielle F, Griveau A, Narboux-Nême N, Vigneau S, Sigrist M, Arber S, Wassef M, Pierani A (2005) Multiple origins of Cajal-Retzius cells at the borders of the developing pallium. Nat Neurosci 8:1002-1012. CrossRef Medline

Borrell V, Marín O (2006) Meninges control tangential migration of hemderived Cajal-Retzius cells via CXCL12/CXCR4 signaling. Nat Neurosci 9:1284-1293. CrossRef Medline

Borrell V, Del Río JA, Alcántara S, Derer M, Martínez A, D’Arcangelo G, Nakajima K, Mikoshiba K, Derer P, Curran T, Soriano E (1999) Reelin regulates the development and synaptogenesis of the layer-specific entorhino-hippocampal connections. J Neurosci 19:1345-1358. Medline

Brunne B, Franco S, Bouché E, Herz J, Howell BW, Pahle J, Müller U, May P, Frotscher M, Bock HH (2013) Role of the postnatal radial glial scaffold for the development of the dentate gyrus as revealed by reelin signaling mutant mice. Glia 61:1347-1363. CrossRef Medline

Catalanotti F, Reyes G, Jesenberger V, Galabova-Kovacs G, de Matos Simoes R, Carugo O, Baccarini M (2009) A Mek1-Mek2 heterodimer determines the strength and duration of the Erk signal. Nat Struct Mol Biol 16:294-303. CrossRef Medline

Del Río JA, Heimrich B, Borrell V, Förster E, Drakew A, Alcántara S, Nakajima K, Miyata T, Ogawa M, Mikoshiba K, Derer P, Frotscher M, Soriano E (1997) A role for Cajal-Retzius cells and reelin in the development of hippocampal connections. Nature 385:70-74. CrossRef Medline

Dougherty MK, Müller J, Ritt DA, Zhou M, Zhou XZ, Copeland TD, Conrads TP, Veenstra TD, Lu KP, Morrison DK (2005) Regulation of Raf-1 by direct feedback phosphorylation. Mol Cell 17:215-224. CrossRef Medline

English JD, Sweatt JD (1997) A requirement for the mitogen-activated protein kinase cascade in hippocampal long term potentiation. J Biol Chem 272:19103-19106. CrossRef Medline

Eswarakumar VP, Lax I, Schlessinger J (2005) Cellular signaling by fibroblast growth factor receptors. Cytokine Growth Factor Rev 16:139-149. CrossRef Medline

Fox IJ, Paucar AA, Nakano I, Mottahedeh J, Dougherty JD, Kornblum HI (2004) Developmental expression of glial fibrillary acidic protein mRNA in mouse forebrain germinal zones: implications for stem cell biology. Dev Brain Res 153:121-125. CrossRef Medline

Frotscher M, Haas CA, Förster E (2003) Reelin controls granule cell migration in the dentate gyrus by acting on the radial glial scaffold. Cereb Cortex 13:634-640. CrossRef Medline

Gil-Sanz C, Franco SJ, Martinez-Garay I, Espinosa A, Harkins-Perry S, Müller U (2013) Cajal-Retzius cells instruct neuronal migration by coincidence signaling between secreted and contact-dependent guidance cues. Neuron 79:461-477. CrossRef Medline

Gorski JA, Talley T, Qiu M, Puelles L, Rubenstein JL, Jones KR (2002) Cortical excitatory neurons and glia, but not GABAergic neurons, are produced in the Emxl-expressing lineage. J Neurosci 22:6309-6314. Medline

Grant SG, O’Dell TJ, Karl KA, Stein PL, Soriano P, Kandel ER (1992) Impaired long-term potentiation, spatial learning, and hippocampal development in fyn mutant mice. Science 258:1903-1910. CrossRef Medline

Hanafusa H, Torii S, Yasunaga T, Nishida E (2002) Sproutyl and Sprouty2 provide a control mechanism for the Ras/MAPK signalling pathway. Nat Cell Biol 4:850-858. CrossRef Medline

Hevner RF, Hodge RD, Daza RA, Englund C (2006) Transcription factors in glutamatergic neurogenesis: conserved programs in neocortex, cerebellum, and adult hippocampus. Neurosci Res 55:223-233. CrossRef Medline

Hodge RD, Nelson BR, Kahoud RJ, Yang R, Mussar KE, Reiner SL, Hevner RF (2012) Tbr2 is essential for hippocampal lineage progression from neural stem cells to intermediate progenitors and neurons. J Neurosci 32:62756287. CrossRef Medline

Hodge RD, Garcia AJ 3rd, Elsen GE, Nelson BR, Mussar KE, Reiner SL, Ramirez JM, Hevner RF (2013) Tbr2 expression in Cajal-Retzius cells and intermediate neuronal progenitors is required for morphogenesis of the dentate gyrus. J Neurosci 33:4165-4180. CrossRef Medline

Imamura O, Pagès G, Pouysségur J, Endo S, Takishima K (2010) ERK1 and ERK2 are required for radial glial maintenance and cortical lamination. Genes Cells 15:1072-1088. CrossRef Medline

Kim AS, Lowenstein DH, Pleasure SJ (2001) Wnt receptors and Wnt inhibitors are expressed in gradients in the developing telencephalon. Mech Dev 103:167-172. CrossRef Medline 
Kuschel S, Rüther U, Theil T (2003) A disrupted balance between Bmp/Wnt and Fgf signaling underlies the ventralization of the Gli3 mutant telencephalon. Dev Biol 260:484-495. CrossRef Medline

Kwon HJ, Ma S, Huang Z (2011) Radial glia regulate Cajal-Retzius cell positioning in the early embryonic cerebral cortex. Dev Biol 351:25-34. CrossRef Medline

Lavado A, Oliver G (2007) Prox1 expression patterns in the developing and adult murine brain. Dev Dyn 236:518-524. CrossRef Medline

Lee SM, Tole S, Grove E, McMahon AP (2000) A local Wnt-3a signal is required for development of the mammalian hippocampus. Development 127:457-467. Medline

Li G, Pleasure SJ (2007) Genetic regulation of dentate gyrus morphogenesis. Prog Brain Res 163:143-152. CrossRef Medline

Li G, Kataoka H, Coughlin SR, Pleasure SJ (2009) Identification of a transient subpial neurogenic zone in the developing dentate gyrus and its regulation by Cxcl12 and reelin signaling. Development 136:327-335. CrossRef Medline

Li X, Newbern JM, Wu Y, Morgan-Smith M, Zhong J, Charron J, Snider WD (2012) MEK is a key regulator of gliogenesis in the developing brain. Neuron 75:1035-1050. CrossRef Medline

Liu M, Pleasure SJ, Collins AE, Noebels JL, Naya FJ, Tsai MJ, Lowenstein DH (2000) Loss of BETA2/NeuroD leads to malformation of the dentate gyrus and epilepsy. Proc Natl Acad Sci U S A 97:865-870. CrossRef Medline

Mazzucchelli C, Vantaggiato C, Ciamei A, Fasano S, Pakhotin P, Krezel W, Welzl H, Wolfer DP, Pagès G, Valverde O, Marowsky A, Porrazzo A, Orban PC, Maldonado R, Ehrengruber MU, Cestari V, Lipp HP, Chapman PF, Pouysségur J, Brambilla R (2002) Knockout of ERK1 MAP kinase enhances synaptic plasticity in the striatum and facilitates striatalmediated learning and memory. Neuron 34:807-820. CrossRef Medline

Meyer G, Cabrera Socorro A, Perez Garcia CG, Martinez Millan L, Walker N, Caput D (2004) Developmental roles of p73 in Cajal-Retzius cells and cortical patterning. J Neurosci 24:9878-9887. CrossRef Medline

Nekrasova T, Shive C, Gao Y, Kawamura K, Guardia R, Landreth G, Forsthuber TG (2005) ERK1-deficient mice show normal T cell effector function and are highly susceptible to experimental autoimmune encephalomyelitis. J Immunol 175:2374-2380. CrossRef Medline

Ohkubo Y, Uchida AO, Shin D, Partanen J, Vaccarino FM (2004) Fibroblast growth factor receptor 1 is required for the proliferation of hippocampal progenitor cells and for hippocampal growth in mouse. J Neurosci 24: 6057-6069. CrossRef Medline

Oliver G, Sosa-Pineda B, Geisendorf S, Spana EP, Doe CQ, Gruss P (1993) Prox 1, a prospero-related homeobox gene expressed during mouse development. Mech Dev 44:3-16. CrossRef Medline

Ortiz J, Harris HW, Guitart X, Terwilliger RZ, Haycock JW, Nestler EJ (1995) Extracellular signal-regulated protein kinases (ERKs) and ERK kinase (MEK) in brain: regional distribution and regulation by chronic morphine. J Neurosci 15:1285-1297. Medline

Paek H, Gutin G, Hébert JM (2009) FGF signaling is strictly required to maintain early telencephalic precursor cell survival. Development 136: 2457-2465. CrossRef Medline

Pierpont EI, Tworog-Dube E, Roberts AE (2013) Learning and memory in children with Noonan syndrome. Am J Med Genet A 161A:2250-2257. CrossRef Medline

Pleasure SJ, Collins AE, Lowenstein DH (2000) Unique expression patterns of cell fate molecules delineate sequential stages of dentate gyrus development. J Neurosci 20:6095-6105. Medline

Pucilowska J, Puzerey PA, Karlo JC, Galán RF, Landreth GE (2012) Disrupted ERK signaling during cortical development leads to abnormal progenitor proliferation, neuronal and network excitability and behavior, modeling human neuro-cardio-facial-cutaneous and related syndromes. J Neurosci 32:8663-8677. CrossRef Medline

Rauen KA (2013) The RASopathies. Annu Rev Genom Hum Genet 14:355369. CrossRef Medline

Rickmann M, Amaral DG, Cowan WM (1987) Organization of radial glial cells during the development of the rat dentate gyrus. J Comp Neurol 264:449-479. CrossRef Medline

Roelink H (2000) Hippocampus formation: an intriguing collaboration. Curr Biol 10:R279-R281. CrossRef Medline

Samuels IS, Karlo JC, Faruzzi AN, Pickering K, Herrup K, Sweatt JD, Saitta SC, Landreth GE (2008) Deletion of ERK2 mitogen-activated protein kinase identifies its key roles in cortical neurogenesis and cognitive function. J Neurosci 28:6983-6995. CrossRef Medline

Samuels IS, Saitta SC, Landreth GE (2009) MAP'ing CNS development and cognition: an ERKsome process. Neuron 61:160-167. CrossRef Medline

Satoh Y, Endo S, Ikeda T, Yamada K, Ito M, Kuroki M, Hiramoto T, Imamura O, Kobayashi Y, Watanabe Y, Itohara S, Takishima K (2007) Extracellular signal-regulated kinase 2 (ERK2) knockdown mice show deficits in long-term memory: ERK2 has a specific function in learning and memory. J Neurosci 27:10765-10776. CrossRef Medline

Satoh Y, Kobayashi Y, Takeuchi A, Pagès G, Pouysségur J, Kazama T (2011) Deletion of ERK1 and ERK2 in the CNS causes cortical abnormalities and neonatal lethality: Erk1 deficiency enhances the impairment of neurogenesis in Erk2-deficient mice. J Neurosci 31:1149-1155. CrossRef Medline

Selcher JC, Atkins CM, Trzaskos JM, Paylor R, Sweatt JD (1999) A necessity for MAP kinase activation in mammalian spatial learning. Learn Mem 6:478-490. CrossRef Medline

Selcher JC, Nekrasova T, Paylor R, Landreth GE, Sweatt JD (2001) Mice lacking the ERK1 isoform of MAP kinase are unimpaired in emotional learning. Learn Mem 8:11-19. CrossRef Medline

Shimogori T, Banuchi V, Ng HY, Strauss JB, Grove EA (2004) Embryonic signaling centers expressing BMP, WNT and FGF proteins interact to pattern the cerebral cortex. Development 131:5639-5647. CrossRef Medline

Sibbe M, Förster E, Basak O, Taylor V, Frotscher M (2009) Reelin and Notch 1 cooperate in the development of the dentate gyrus. J Neurosci 29:8578-8585. CrossRef Medline

Simon R, Brylka H, Schwegler H, Venkataramanappa S, Andratschke J, Wiegreffe C, Liu P, Fuchs E, Jenkins NA, Copeland NG, Birchmeier C, Britsch S (2012) A dual function of Bcl11b/Ctip2 in hippocampal neurogenesis. EMBO J 31:2922-2936. CrossRef Medline

Stanfield BB, Cowan WM (1979) The development of the hippocampus and dentate gyrus in normal and reeler mice. J Comp Neurol 185:423-459. CrossRef Medline

Storm EE, Garel S, Borello U, Hebert JM, Martinez S, McConnell SK, Martin GR, Rubenstein JL (2006) Dose-dependent functions of Fgf8 in regulating telencephalic patterning centers. Development 133:1831-1844. CrossRef Medline

Sugiyama T, Osumi N, Katsuyama Y (2013) The germinal matrices in the developing dentate gyrus are composed of neuronal progenitors at distinct differentiation stages. Dev Dyn 242:1442-1453. CrossRef Medline

Tartaglia M, Gelb BD (2010) Disorders of dysregulated signal traffic through the RAS-MAPK pathway: phenotypic spectrum and molecular mechanisms. Ann N Y Acad Sci 1214:99-121. CrossRef Medline

Thomas GM, Huganir RL (2004) MAPK cascade signalling and synaptic plasticity. Nat Rev Neurosci 5:173-183. CrossRef Medline

Thomson RE, Pellicano F, Iwata T (2007) Fibroblast growth factor receptor 3 kinase domain mutation increases cortical progenitor proliferation via mitogen-activated protein kinase activation. J Neurochem 100:15651578. CrossRef Medline

Tidyman WE, Rauen KA (2009) The RASopathies: developmental syndromes of Ras/MAPK pathway dysregulation. Curr Opin Genet Dev 19: 230-236. CrossRef Medline

Yang A, Walker N, Bronson R, Kaghad M, Oosterwegel M, Bonnin J, Vagner C, Bonnet H, Dikkes P, Sharpe A, McKeon F, Caput D (2000) p73deficient mice have neurological, pheromonal and inflammatory defects but lack spontaneous tumours. Nature 404:99-103. CrossRef Medline

Yoon G, Rosenberg J, Blaser S, Rauen KA (2007) Neurological complications of cardio-facio-cutaneous syndrome. Dev Med Child Neurol 49: 894-899. CrossRef Medline

Yoshinaga Y, Kagawa T, Shimizu T, Inoue T, Takada S, Kuratsu J, Taga T (2010) Wnt3a promotes hippocampal neurogenesis by shortening cell cycle duration of neural progenitor cells. Cell Mol Neurobiol 30:1049_ 1058. CrossRef Medline

Yu DX, Marchetto MC, Gage FH (2014) How to make a hippocampal dentate gyrus granule neuron. Development 141:2366-2375. CrossRef Medline

Zenker M (2011) Clinical manifestations of mutations in RAS and related intracellular signal transduction factors. Curr Opin Pediatr 23:443-451. CrossRef Medline

Zhou CJ, Zhao C, Pleasure SJ (2004) Wnt signaling mutants have decreased dentate granule cell production and radial glial scaffolding abnormalities. J Neurosci 24:121-126. CrossRef Medline 